GEOLOGICAL SURVEY CIRCULAR 669

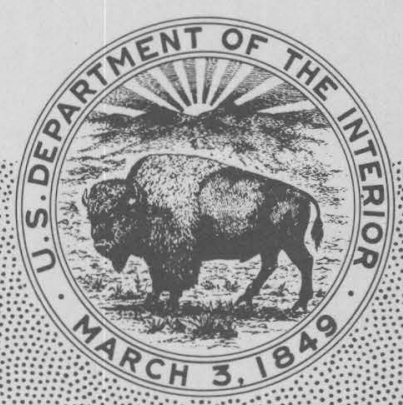

Mineral Resources Off the

Northeastern Coast of

the United States 



\title{
Mineral Resources Off the Northeastern Coast of the United States
}

\author{
By Frank T. Manheim
}

GEOLOGICAL SURVEY CIRCULAR 669 
United States Department of the Interior ROGERS C. B. MORTON, Secretary

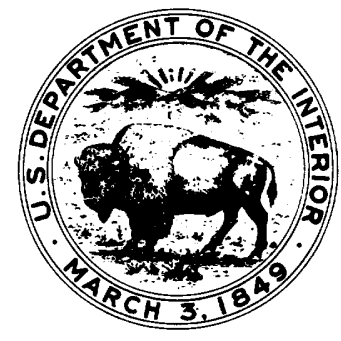

Geological Survey

V. E. McKelvey, Director 


\section{CONTENTS}

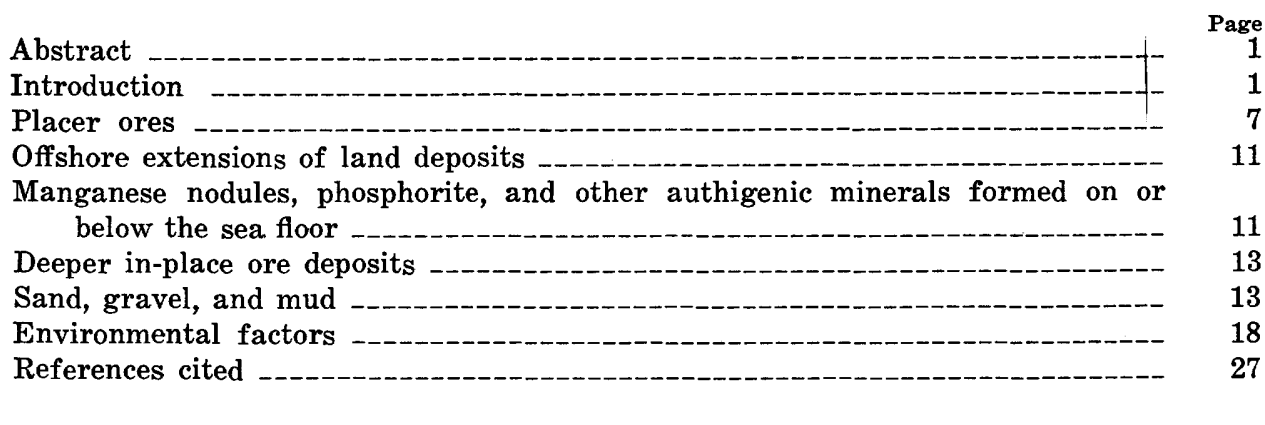

\section{ILLUSTRATIONS}

FIGURE 1. Simplified bathymetric map of northeastern offshore region, United States and maritime Canada

2. Schematic diagram showing maximum glacial advance off Northeastern United States ------

3. Map showing distribution of calcium carbonate in bottom sediments off Northeastern United States

4. Generalized geologic map of coastal Northeastern United States and part of the Maritime Provinces of Canada

5. Structure cross sections of the Gulf of Maine

6. Maps showing location of sampling stations of the U.S. Geological Survey-Woods Hole Oceanographic Institution Continental Margin Program

7. Map showing distribution of middle Tertiary phosphate-bearing sediments along the eastern continental margin of North America

8. Schematic drawing showing transport of material from outcrop by glacial action

9-17. Maps showing:

9. Copper and zinc content of moraine near the Noranda ore body, Canada

10. Distribution of spotted schist pebbles on the southeastern Scotian Shelf

11. Distribution of sand on the continental margin off Northeastern United States --.-

12. Distribution of sand and gravel off New Jersey

13. Distribution of sand in the inner Gulf of Maine and Massachusetts Bay

14. Distribution of gravel on the continental margin off Northeastern United States --.--

15. Distribution of gravel in the inner Gulf of Maine and Massachusetts Bay -...-..--

16. Offshore distribution of sediments that can be used in an innovative ceramic manufacturing process

17. Directions of residual current along the bottom on the continental shelf and directions and magnitudes of sand movement on the beaches

18. Diagram showing balance of dredge spoil and consumption of sand and gravel for Atlantic Coast States 


\section{TABLES}

TABLE 1. Chemical and modal analyses of typical sea-floor deposits on the northeastern continental margin of the United States

Page

. Quantity and value of sand and gravel production for various uses in the United States in 1970

3. Quantity and value of sand and gravel and stone produced by some northeastern States, 1970 


\title{
Mineral Resources off the Northeastern Coast of the United States
}

\author{
By Frank T. Manheim
}

\begin{abstract}
Sand, gravel, and mud represent not only the largest potential but also the most immediately useful sea-floor resources off the coast of the Northeastern United States. Reserves of surficial sand grading 75 percent or more amount to more than 400 billion tons in the upper 3 meters (10 ft) of the sea floor; this is enough to supply the sand needs of the Northeastern States of the United States and Maritime Provinces of Canada for several thousand years.

Utilization of fine muds may be possible through innovative technology and should be encouraged. The mounting quantity of spoils produced by dredging of harbors and waterways otherwise poses a threat to the environment.

Significant placer or other ores are not promising in surficial deposits. In the Gulf of Maine the existence of ores beneath glacial deposits remains unknown in the absence of core drilling to probe pre-Tertiary sedimentary and metamorphic rocks.

No leasing is now permitted pending reevaluation of Federal and State regulatory guidelines. Improved investigatory and regulatory systems are essential to determine the guidelines for and to permit judicious and environmentally compatible management of offshore resources.
\end{abstract}

\section{INTRODUCTION}

The area off the coast of the Northeastern United States to the edge of the continental shelf encompasses about $250,000 \mathrm{~km}^{2}$ (square kilometers) or about 100,000 square miles (fig. 1). This area is only a little smaller than the combined area of New Jersey, New York, Connecticut, Rhode Island, Massachusetts, New Hampshire, and Maine. Except for bays and estuaries, and basins within the Gulf of Maine, most of the area is covered with relic sand, silt, and gravel, which are remnants of glacial or glacial-outwash deposits. As may be seen in figure 2 , the entire area was either covered by glaciers some 15,000 years ago or was affected by outwash from melting glaciers. Ice-rafted material that ranges in size from sand to boulders is found on the sea bottom well beyond the shelf break into the continental-slope region. The shelf break generally begins at a depth of from 120 to $140 \mathrm{~m}$ (meters), but most of the shelf is considerably shallower than this, except for basins deeper than $200 \mathrm{~m}$ in the Gulf of Maine. Below the shelf break, finer and more carbonate-rich sediments dominate (fig. 3).

Oil, gas, and sulfur are not included in this summary, which focuses on relatively shallow earth materials found on the shelf and in bays, estuaries, and tidal rivers along the coast. The kinds of sediment found in the offshore sea bottom reflect in part the geology of the adjoining land (fig. 4), but some long distance transport is involved, and an enormous amount of mixing and homogenization was performed by the scraping actions of the ice sheets, combined with the postmelting processes of deposition by streams and transport and winnowing by waves and currents.

Because of the blanket of glacially related sediments over much of the shelf, knowledge of the subsurface is based chiefly on geophysical (seismic, gravity, magnetic) measurements, samples from outcrops of bedrock in submarine canyons at the shelf break, and extrapolation of land geology. The subsurface geology off New Jersey and New York consists largely of Quaternary-to-Mesozoic sedimentary layers dipping seaward. North of Long Island, however, only shallow layers of sediment, a few tens or hundreds of meters thick, overlie complex preTriassic metamorphic or crystalline rocks in 


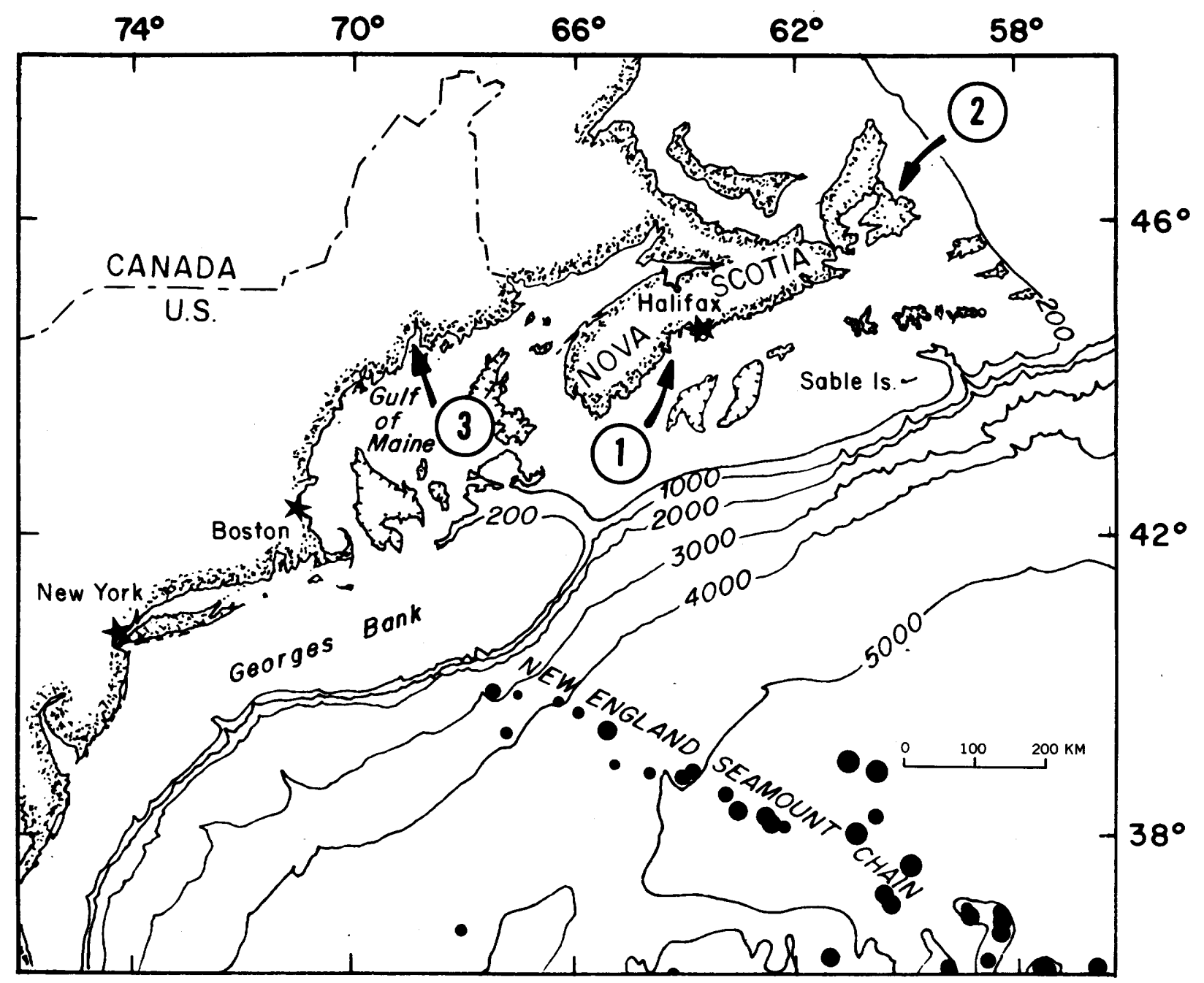

FIGURE 1.-Simplified bathymetric map of northeastern offshore region, United States and maritime Canada (modified from Emery and others, 1970). Solid circles indicate seamounts off New England. 1, gold deposits near Lunenberg Bay, Nova Scotia; 2, coal mines off Sydney-Glace Bay, Cape Breton Island; 3, copper-zinc district, Penobscot Bay, Maine. Contours in meters.

the nearshore region (fig. 5). Farther offshore, wedges of Tertiary-to-Mesozoic sedimentary rocks thicken rapidly seaward. Petroleum prospects are restricted to the thicker sedimentary rocks, as noted by Maher (1971) and work cited therein and by Tucker. ${ }^{1}$

The largest body of data on the sediments of the shelf region has been accumulated through surface-sediment samplings by the U.S. Geological Survey-Woods Hole Oceanographic Institution Continental Margin Program, which

\footnotetext{
1 L. R. Tucker, 1971, East coast oil and gas potential: Report presented at Conference on World Ocean Resources, New York Univ., November 1971.
}

began in $1962 .{ }^{2}$ Location of the sampling stations, raw data from which are available in a recent computerized compilation (Hathaway, 1971), are given in figure 6 . These collections were largely made by surface grab samples which obtained material from a depth of 10 to about $30 \mathrm{~cm}$ (centimeters). Gravity and piston cores have been obtained chiefly by coring in muddy basins in the Gulf of Maine, Buzzards Bay, canyons, and estuaries; such coring is

2 The Bureau of Commercial Fisheries, Woods Hole (now North Atlantic Fisheries Research Center, National Oceanic and Atmospheric Administration), also collaborated in the program and has tabulated faunal populations noted in the bottom sediments. 


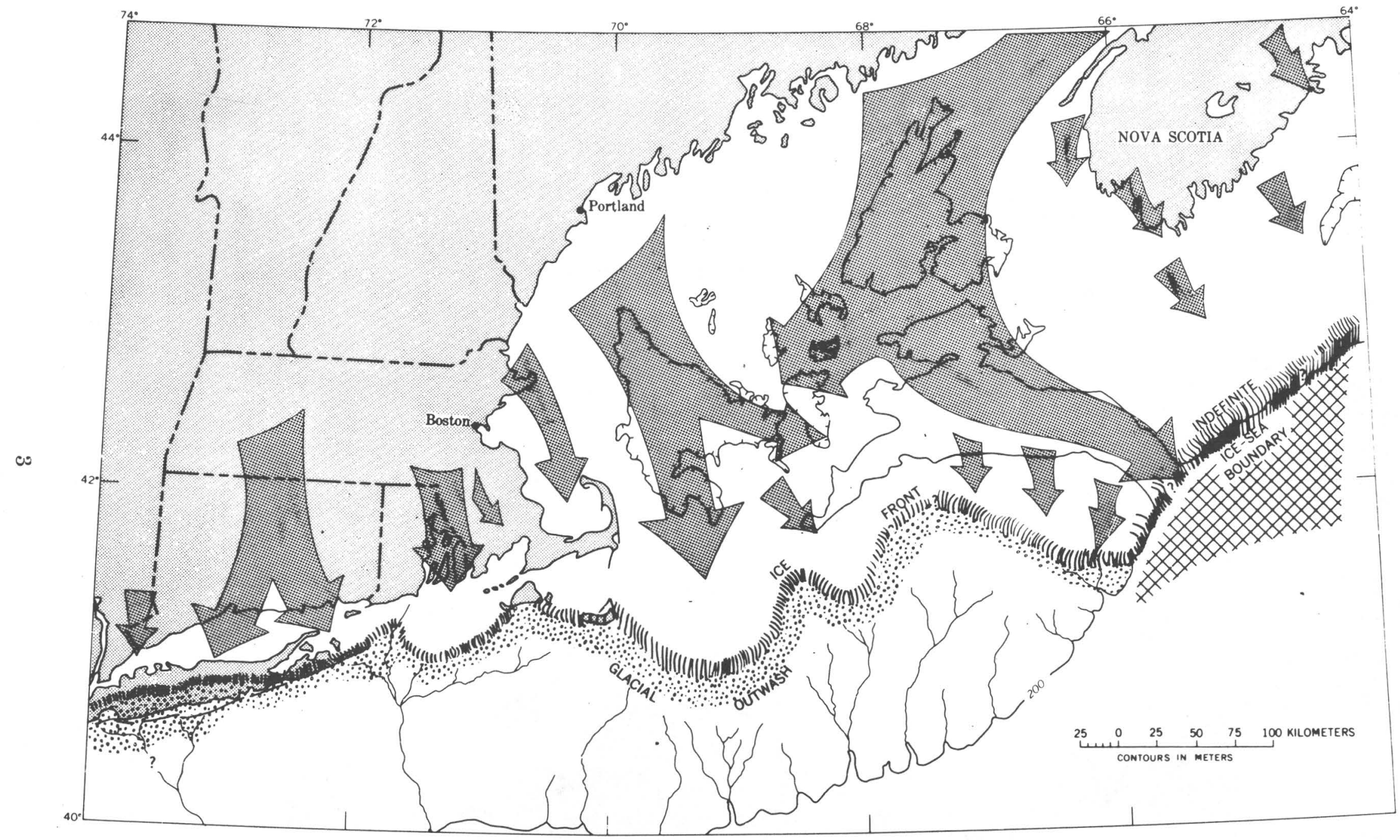

FIGURE 2.-Schematic diagram showing maximum glacial advance off Northeastern United States. Arrows indicate major currents of movement of the ice sheet. From Schlee and Pratt (1970, fig. 15). 


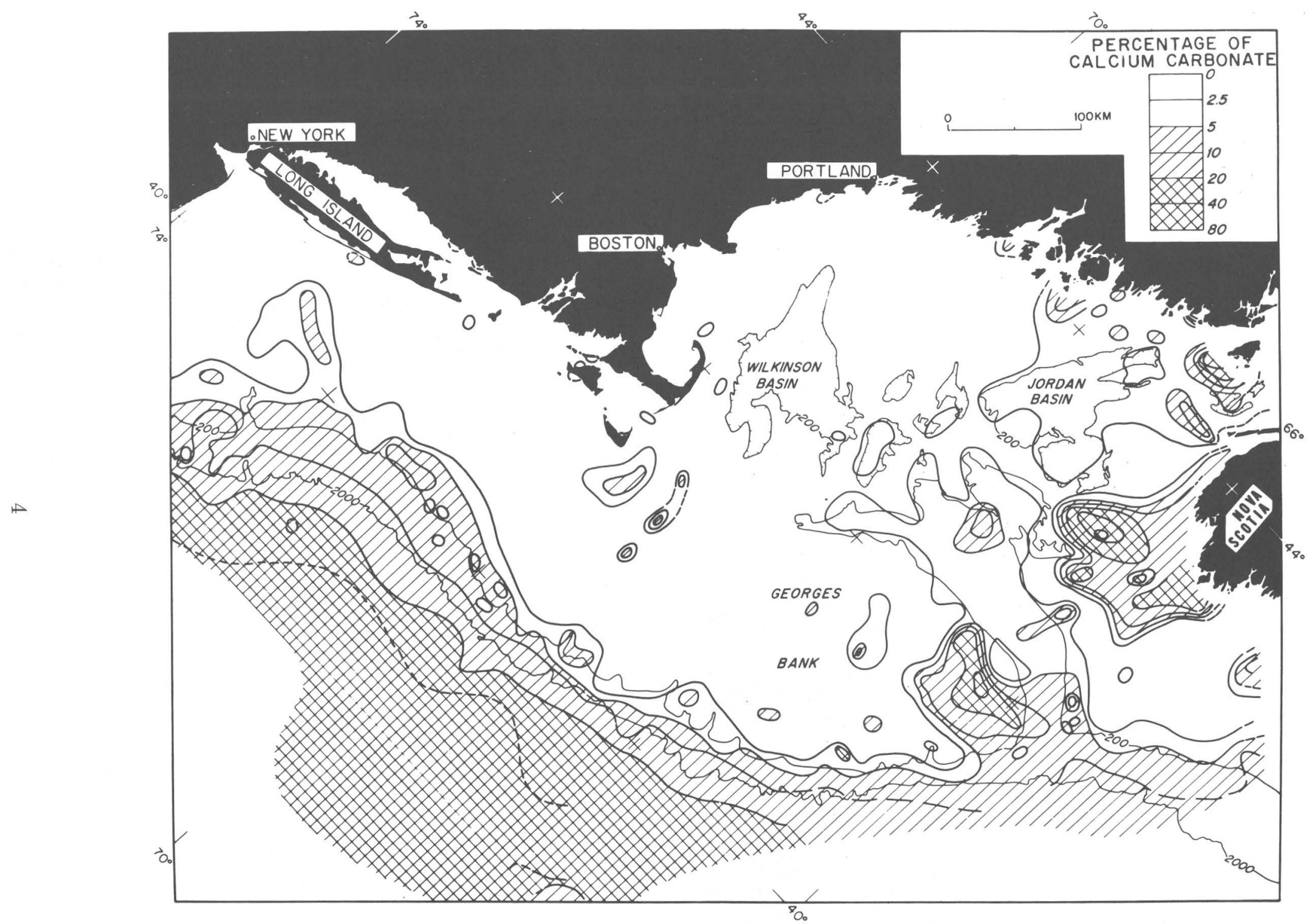

FIGURE 3.-Distribution of calcium carbonate in bottom sediments off Northeastern United States (from Hülsemann, 1967; reprinted from "Sedimentology", with permission of Elsevier Publishing Co.). Concentrations are in percent air dry weight; depth contours in meters. 


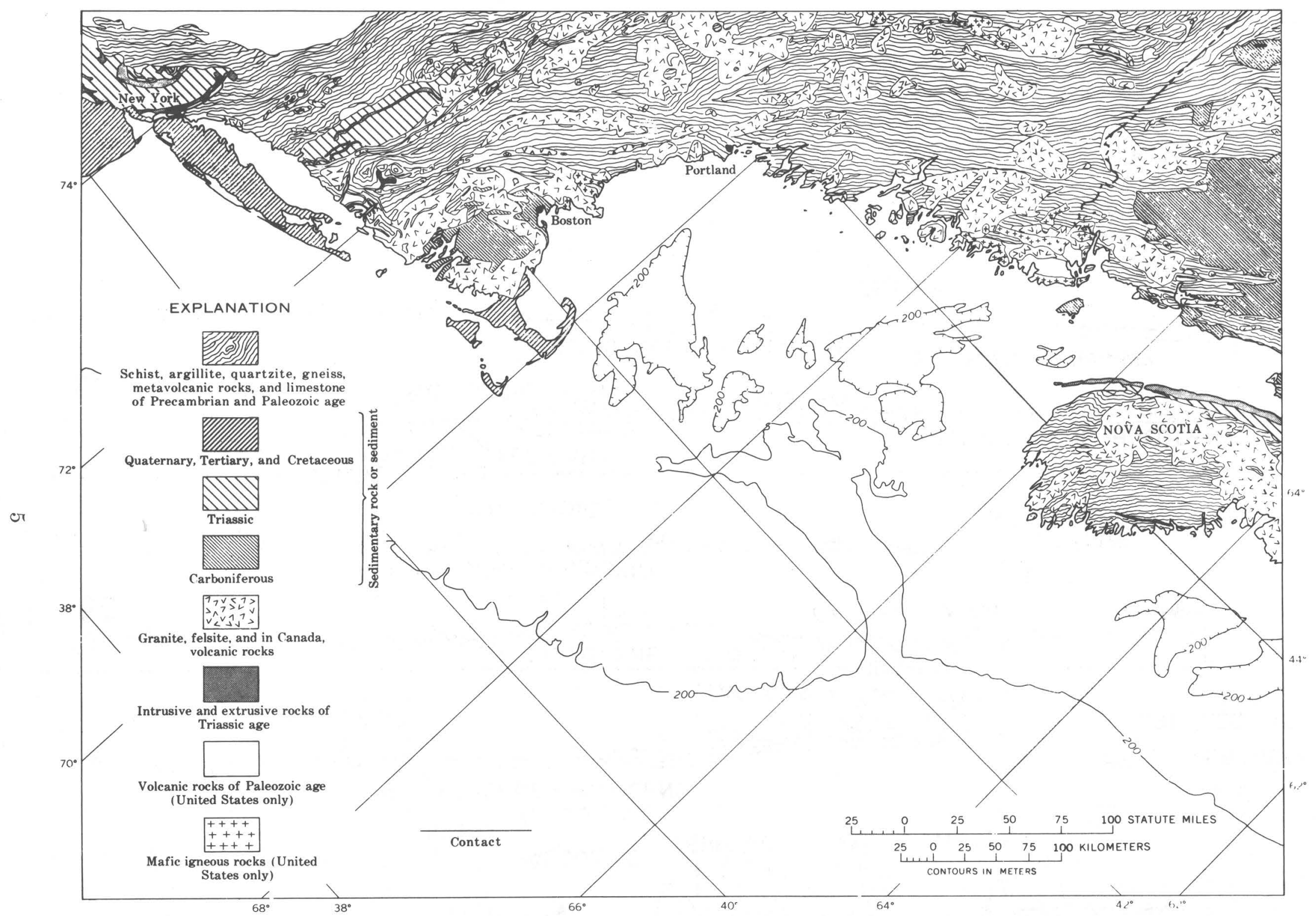

FIgURe 4.-Generalized geologic map of coastal Northeastern United States and part of the Maritime Provinces of Canada. Modified from Goldsmith (1964) and Canada Geological Survey (1949), in Schlee and Pratt (1970). 


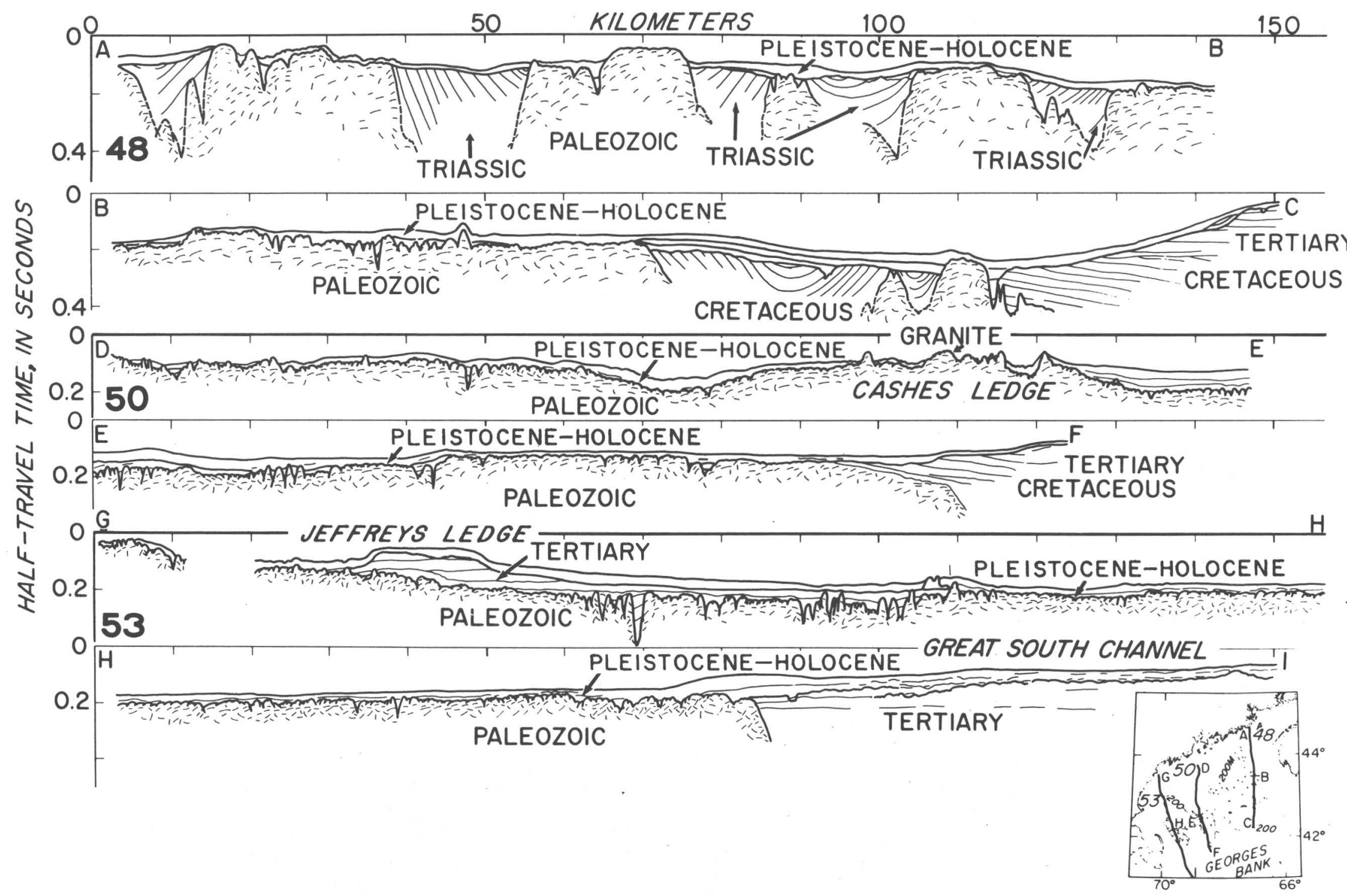

FIGURE 5.-Structure cross sections of the Gulf of Maine (from Uchupi, 1966; reprinted from "Journal of Geophysical Research" with permission of American Geophysical Union). 
difficult in sands or coarser materials on the shelf proper. However, the U.S. Army Coastal Engineering Research Center (Washington, D.C.) has taken more than 300 vibro cores that reached depths of about $6 \mathrm{~m}$, from New Jersey northward. With the exception of their program in Cape Cod Bay, most of the Corps of Engineers' work is directed toward beach-sand replenishment sources within 10 miles of land or shallower than 100 feet $(30 \mathrm{~m})$ of water. This work is summarized briefly by Duane (1969).

Few deeper samplings are available. Schlee (1968) listed the following drill holes and information from them:

Ambrose Light Station ___-20-196 ft of silty sand to and Scotland Light towers gravel above gray clay. at the approaches to New York Harbor.

Texas tower site, south _-- $70 \mathrm{ft}$ of coarse sand and of Moriches Bay, Long fine gravel overlying silty Island.

Nantucket Shoals _._____-_80-90 ft of sand and gravelly sand above silty clay.

Georges Shoal (250 km _-_. As much as $120 \mathrm{ft}$ of fine to northeast of above). coarse sand.

In addition to the above, E. H. Goodwin, U.S. Coast Guard, Boston, Mass. (oral commun., 1972), provided data on several other foundation borings made for the Coast Guard in the New England offshore region:

Portland, Maine, lat _-_-_Bedrock encountered from $43^{\circ} 30^{\prime} 42^{\prime \prime} \mathrm{N}$., long $70^{\circ} 4^{\prime}$ just below sea bottom to $57^{\prime \prime} \mathrm{W}$. (about 11 nautical some $11 \mathrm{ft}$ or more below miles southeast of Port- sea bottom.

land).

800 feet off tip of _-_._- $50 \mathrm{ft}$ of chiefly medium to Monomoy Point, Mass. coarse sand with trace of gravel.

Cross Rip light, south of _- 0-10 ft, sand; 10-20, shell Hyannisport, Mass., lat fragments; at 20, silt; $41^{\circ} 26^{\prime} 39^{\prime \prime}$ N., long $17^{\circ} 17^{\prime} 35$, many shell fragments; $36^{\prime \prime} \mathrm{W}$. Measurements are 46, less shell fragments; in feet below sea bottom. 59, fine gravel and sand; 65 , dense gray medium sand; 85, fine stiff clay, silty clay; 99-100, sand layers; 109, stiff gray silty to clayey sand; 119 , silty sand; 125, less silt; 135, shell fragments and coarse sand; 149 very fine gray sand.

Buzzards Bay tower

Bottom (61 ft) to $91 \mathrm{ft}$, sand; at $91 \mathrm{ft}$, gravelly layers, 1 to 2 inches thick; 91-268 ft, clay, sand, gravel and possible boulders; $268 \mathrm{ft}$, bedrock.

Brenton Reef, lat $41^{\circ} 25^{\prime} 35^{\prime \prime}$ _Bedrock at $77 \mathrm{ft}$ water N., long $71^{\circ} 23^{\prime} 20^{\prime \prime}$ W., off depth (no sediment) ; 77Newport, R.I.

$112 \mathrm{ft}$, metamorphic rock.

No mineral deposits are now being exploited on the offshore sea floor, except for coastal dredge and fill operations and beach restoration. The future value of mineral resources in the area is great, but as several researchers have indicated, the immediate promise is not in valuable metal ores, but in such unglamorous or apparently uninteresting materials as sand, gravel, and mud, which are available in huge quantities. However, to develop these resources and meet the anticipated needs of the northeastern coastal communities, several still unfulfilled conditions will probably have to be met. Chief among these is a positive, fully implemented and well-coordinated investigatory and regulatory system involving both state and federally controlled offshore lands. The purpose of this paper is to sketch some of the facts and factors involved in achieving these goals.

I am indebted most of all to J. S. Schlee (U.S. Geological Survey, Woods Hole), who provided the core of published and unpublished information on which this paper is based. K. O. Emery (Woods Hole Oceanographic Institution) also provided much help and useful discussion. Others who have been helpful are R. Wigley, North Atlantic Fisheries Research Center, Woods Hole; D. B. Duane, Corps of Engineers, Washington, D.C.; V. L. Andreliunas and D. Leifer, Corps of Engineers, North Atlantic Div.; R. Blumberg, Massachusetts Department of Natural Resources; J. I. Tracey, Jr., U.S. Geological Survey, Washington, D.C.; R. H. Meade, U.S. Geological Survey, Woods Hole, Mass.; Frank Shea of the Nova Scotia Department of Mines; and E. H. Goodwin of the U.S. Coast Guard in Boston.

\section{PLACER ORES}

The term "offshore mineral resources" frequently conjures up valuable commodities or raw materials such as phosphorite, placer (transported by running water) gold, platinum, diamonds, tin, monazite (thorium-rare earth 


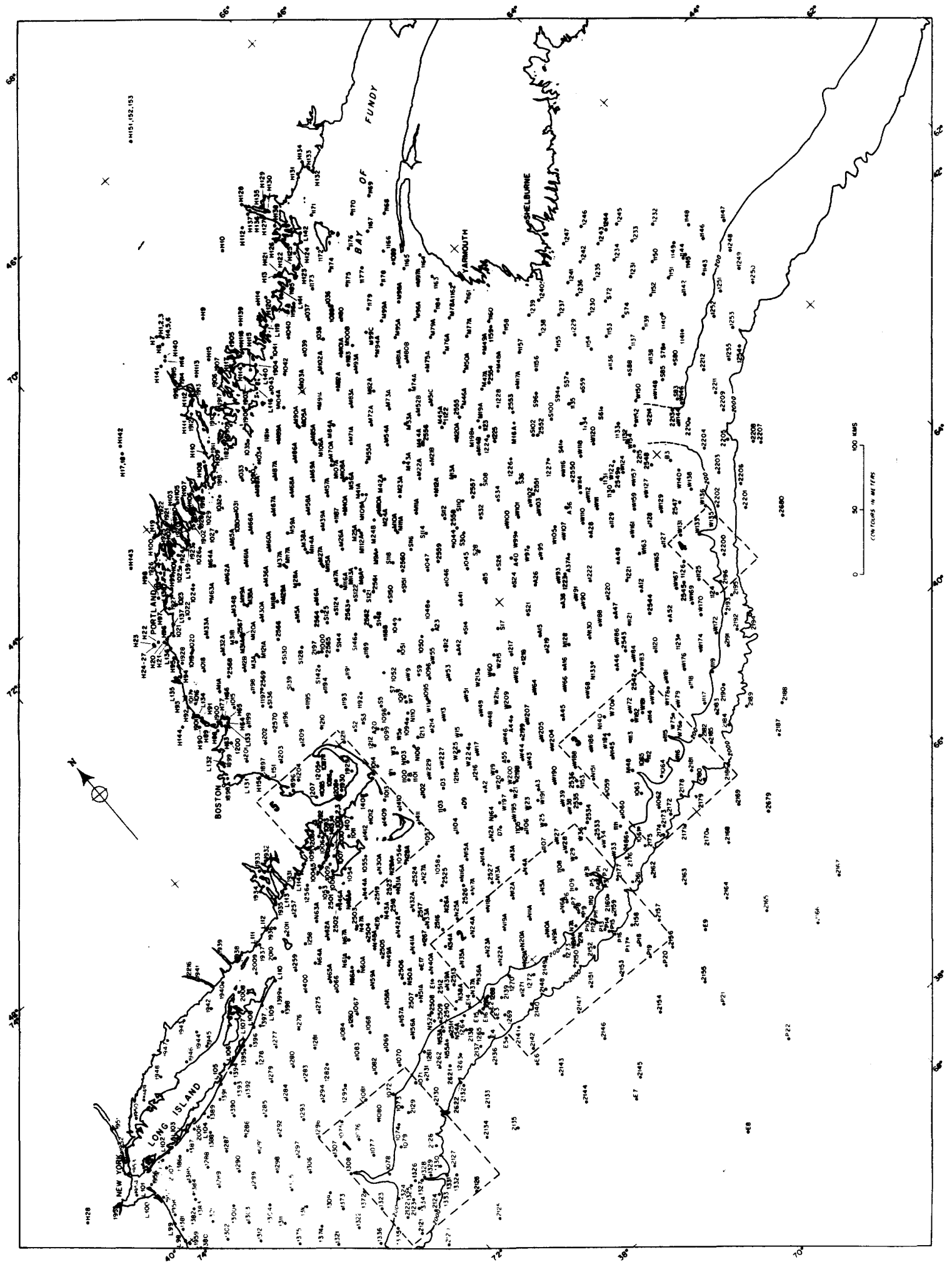




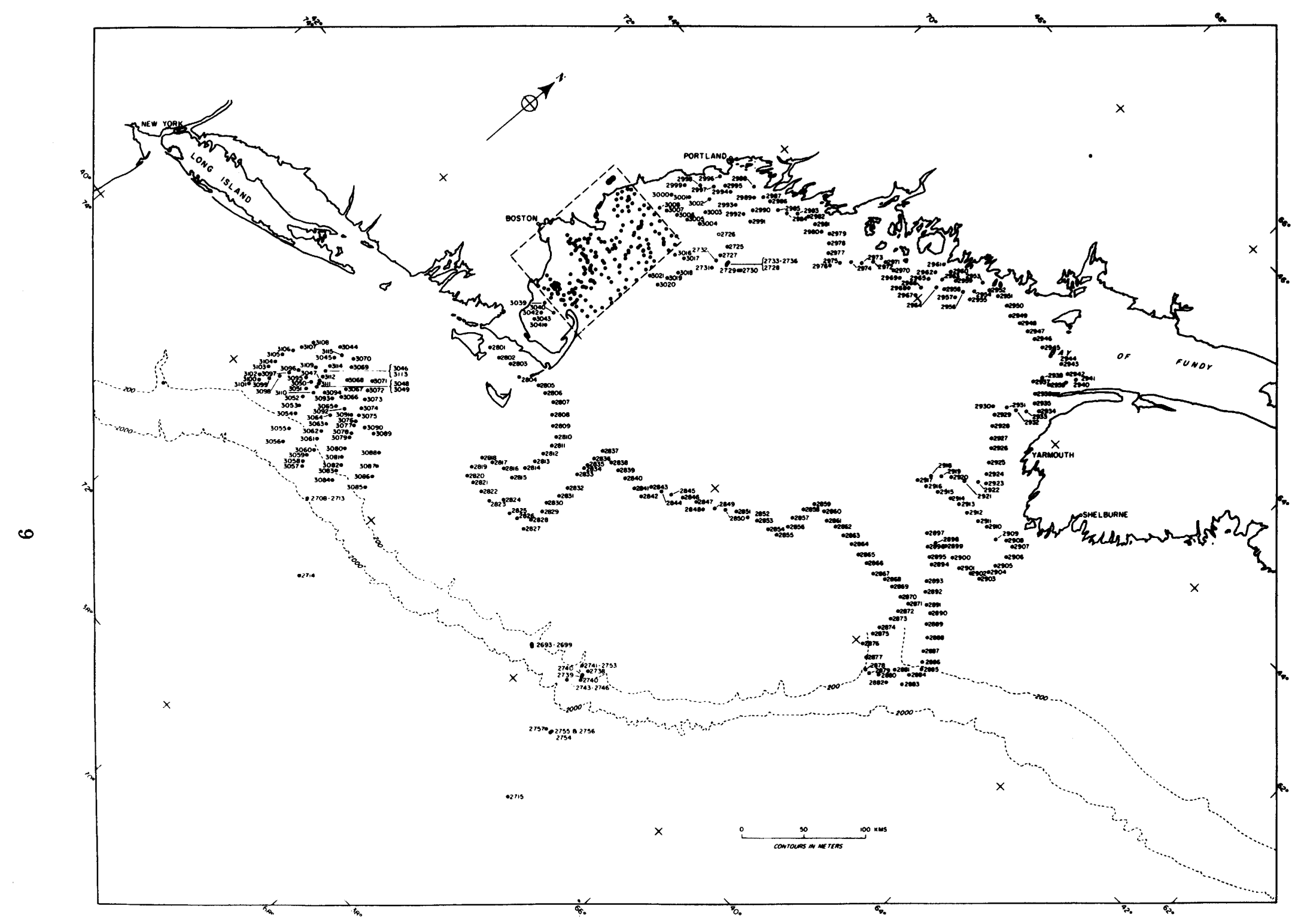

FIGURE 6.-Location of sampling stations of the U.S. Geological Survey-Woods Hole Oceanographic Institution Continental Margin Program (documented in Hathaway, 1971). Top: Stations as of January 1, 1967. Bottom: Stations added after January 1, 1967. Numbered areas contain additional sampling stations that are too closely spaced to show at this scale. These stations are given in Hathaway (1971). 
phosphates), zircon, and titanium ores such as rutile and ilmenite. However, although all of the above occur offshore and have either been sought, considered for exploitation, or mined somewhere in the world (McKelvey and Wang, 1969), only tin (Indonesia-Malaya) and diamonds (Southwest Africa-production now abandoned) have yielded as much as a million dollars in value per year (Emery, 1966; Emery and Noakes, 1968).

The prospects for finding significant beach or offshore placer deposits along the northeastern coast of North America are diminished by the repeated glaciation of the area. The vast amount of ground-up country rock supplied from moraines and outwash plains in glacial areas tends to dilute segregations of heavy minerals. ${ }^{3}$ Many sites of uneconomic dark (heavy) mineral concentrations were reported along Cape Cod beaches by Trumbull and Hathaway (1968), who covered 255 km (kilometers) or about 160 miles of shoreline from Scituate to the Elizabeth Islands, Mass., in 2 days by helicopter survey. The accumulations were mainly thin surface dustings or deposits of limited thickness, concentration, or extent. The dark minerals consisted largely of small garnets which are not of gem quality and very common in low- to medium-grade metamorphic rocks such as schists.

Total concentration of heavy minerals (that is, heavier than a specific gravity of about 3.0) ranges generally from 1 to 4 percent in surficial shelf sediments off the Northeastern United States. Of the heavy minerals, 30 to 50 percent are generally opaque grains (Ross, 1970, and cited in Hathaway, 1971) such as magnetite, ilmenite (iron-titanium oxide), and limonite (hydrous iron oxide). In the nonopaque fraction, garnets and iron-magnesium-calciumaluminum silicates such as amphiboles, epidote, augite, and staurolite dominate. Mineral and chemical analyses of a typical heavy mineral fraction from sand south of Long Island are given in table 1 , along with the composition of other typical offshore sediments. Some dark minerals are not heavy. These include glauconite (iron-potassium-aluminum silicate related to

\footnotetext{
${ }^{3}$ Glacial action, however, may sometimes aid in prospecting for in-place ore bodies. See "Deeper In-Place Ore Deposits."
}

potassium micas), iron-stained quartz, and artificially introduced products such as coal and slag particles.

Rather ordinary beach sands are sometimes mined for heavy minerals such as rutile, ilmenite, zircon, and monazite, even though total heavy minerals amount to as little as $11 / 2$ percent. This may be done under stable price conditions where large-scale mining and advanced techniques for separating the minerals are applied, as in coastal Georgia and the east coast of Australia (Emery and Noakes, 1968). For the Australian deposits the cutoff grade is about 0.3 percent rutile $\left(\mathrm{TiO}_{2}\right)$ and 0.3 percent zircon $\left(\mathrm{ZrSiO}_{4}\right)$. Offshore, however, higher costs and the impracticability of selective mining suggest that overall grades must be higher, even for shallow waters.

Rutile and zircon are scarce in shelf sands from the present area of interest and normally are less than 0.05 percent of the total sediment (from data by D. A. Ross in Hathaway, 1971). Though not investigated mineralogically, the opaque fraction of the heavy minerals must contain appreciable titanium minerals, probably largely ilmenite, to judge from the typical heavy mineral sample analyzed and presented in table 1 , sample 4 (12 percent $\mathrm{TiO}_{2}$ ), and from the several tenths of a percent $\mathrm{TiO}_{2}$ generally found in shelf sands. Nevertheless, this titanium concentration is no doubt well below concentrations necessary to offer mining potential.

Though not rich enough in valuable minerals to attract commercial interest, the sands are too impure to serve as "glass" sands for glassmaking. Such sands must be very low in iron and other metals which can impart undesirable color and other properties to the glass. Other aspects of the sands are mentioned later.

Thus, no valuable placer deposits have been found or are currently likely on the continental margin of the United States, but attempts to explore for and mine placer gold were made by a commercial firm off the south shore of Nova Scotia near Lunenberg Bay (south of Halifax). A small seagoing dredge was employed less than 1 mile seaward of the coast (fig. 1) to mine placer gold in submerged stream deposits presumably eroded from the known gold-bearing Halifax slates and Goldenville quartzites of Ordovician age. Values of up to $\$ 4$ per cubic 
TABLE 1.-Chemical and modal analyses of typical seafloor deposits on the northeastern continental margin of the United States

[Data from J. A. Hathaway (X-ray analysis), D. A. Ross (heavy minerals), and F. T. Manheim (chemical), compiled in Hathaway (1971), and unpublished data. All data in weight percent; values in parentheses are approximate. Location of stations shown in upper part of fig. 6]

\begin{tabular}{|c|c|c|c|c|c|}
\hline & 1 & 2 & 3 & 4 & 5 \\
\hline \multicolumn{6}{|c|}{ Chemical analyses } \\
\hline $\begin{array}{ll}\mathrm{SiO}_{2} & \\
\mathrm{TiO}_{2} & \\
\mathrm{Al}_{2} \mathrm{O}_{3} & \\
\mathrm{Fe}_{2} \mathrm{O}_{3} & \end{array}$ & $\begin{array}{c}64.2 \\
.67 \\
10.8 \\
.54\end{array}$ & $\begin{array}{c}50.4 \\
.69 \\
15.9 \\
3.2\end{array}$ & $\begin{array}{c}92.6 \\
.23 \\
2.6 \\
.30\end{array}$ & $\begin{array}{l}28.8 \\
12.0 \\
19.1\end{array}$ & $\begin{array}{c}51.4 \\
.60 \\
10.0 \\
1.1\end{array}$ \\
\hline $\begin{array}{l}\mathrm{FeO} \\
\mathrm{MgO} \\
\mathrm{CaO} \\
\mathrm{MnO} \\
\mathrm{Na}_{2} \mathrm{O} \\
\mathrm{K}_{2} \mathrm{O} \\
\mathrm{P}_{2} \mathrm{O}_{5} \\
\mathrm{H}_{2} \mathrm{O} \\
\mathrm{H}_{2} \mathrm{O}^{+} \\
\mathrm{CO}_{2} \\
\mathrm{C} \text { (organic) } \\
\mathrm{N} \text { (orges } \\
\text { Volatiles other than } \\
\mathrm{CO}_{2} \text { and } \mathrm{H}_{2} \mathrm{O}^{2} \text {. }\end{array}$ & $\begin{array}{c}2.6 \\
1.7 \\
.84 \\
.04 \\
13.3 \\
2.0 \\
.18 \\
2.3 \\
4.3 \\
.12 \\
3.5 \\
.17\end{array}$ & $\begin{array}{c}3.0 \\
3.0 \\
1.3 \\
.11 \\
13.8 \\
3.6 \\
.20 \\
3.3 \\
5.6 \\
.69 \\
1.9 \\
.27\end{array}$ & $\begin{array}{l}.25 \\
.4 \\
.18 \\
.03 \\
.50 \\
.63 \\
.03 \\
.02 \\
.98 \\
.06 \\
.05 \\
.004\end{array}$ & $\begin{array}{c}4.4 \\
9.1 \\
1.0 \\
.3 \\
.47 \\
.26 \\
-- \\
-.1 \\
.05 \\
--\end{array}$ & $\begin{array}{c}1.6 \\
2.0 \\
8.9 \\
\overline{14.0} \\
2.2 \\
.14 \\
2.4 \\
3.7 \\
5.5 \\
.7 \\
.11 \\
5.8\end{array}$ \\
\hline Sum & 100 & 999 & 99 & 497 & 99 \\
\hline
\end{tabular}

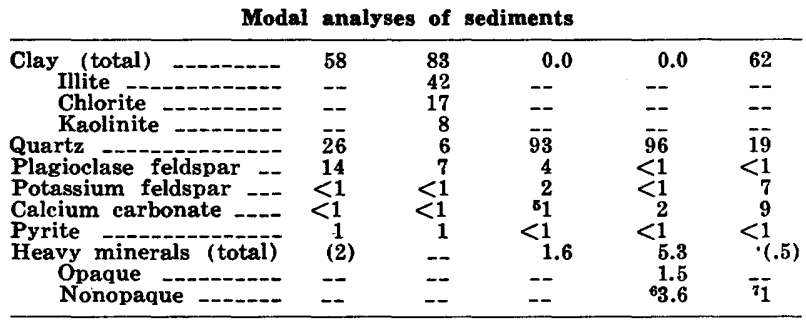

1 Most of the sodium is present as dried sea salt.

2 Includes organic carbon and nitrogen.

3 Also contains $\mathrm{S}, 0.52$; $\mathrm{HCl}$-soluble sulfate reported as $\mathrm{SO}_{3}, 0.15$; and F, 0.12 .

Also contains $\mathrm{Sr}, 0.01, \mathrm{Ni}, 0.01, \mathrm{Zn}, 0.062, \mathrm{Ba}, 0.01$.

5 Aragonite from broken mollusk shells.

6 Composition of nonopaque fraction, in percent: garnet, 42; staurolite, 30; augite, 8; amphiboles, 8; tourmaline, 5; epidote, hypersthene, kyanite, and titanite, 2 to 4 each; and zircon 1 . Hornblende.

1. Sta. 1913, river mouth estuarine mud, Penobscot River, Maine, lat $44^{\circ} 28.7^{\prime}$ N., long $68^{\circ} 47.7^{\prime}$ W.; water depth, $18 \mathrm{~m}$; silty gray-brown clay with twigs, worms, and shell fragments.

2. Sta. 2197, terrigenous mud, Wilkinson Basin, Gulf of Maine, lat $42^{\circ} 34.7^{\prime} \mathrm{N}$., long $69^{\circ} 32.6^{\prime} \mathrm{W}$.; depth, $290 \mathrm{~m}$; very fine gray clayey mud.

3. Sta. N14, shelf sand off Nantucket, lat $40^{\circ} 43^{\prime} \mathrm{N}$., long $69^{\circ} 45^{\prime}$ W.; depth, $47 \mathrm{~m}$; tan-gray clean sand.

4. Sta. 1387, shelf sand south of Long Island, lat $40^{\circ} 30.3^{\prime} \mathrm{N}$., long W.; depth, $20 \mathrm{~m}$; chemical analysis on heavy-mineral raction. In modal analysis, sum of more than 100 is probably

due in part to sample inhomogeneity.

Sta. P15, continental slope sediment off Cape Cod, lat $39^{\circ} 44^{\prime} \mathrm{N}$.

yard of sediment were reported in a rather glowing account (Libby, 1969). Since then, however, mining activities have evidently ceased (Frank Shea, Nova Scotia Department of Mines, oral commun., 1971). Instead, large beds of sea clams and scallops which were found during the gold search are being exploited.

\section{OFFSHORE EXTENSIONS OF LAND DEPOSITS}

In many parts of the world, mineral deposits known or mined on land extend into the adjoin- ing submerged shelf. In some cases, boreholes or other workings are directed under the sea floor from the land itself. Coal mining under the sea adjoining Cape Breton Island (Canada) is the only such activity currently known off the coast of northeastern North America. Near Sydney and Glace Bay on the northern coast of Cape Breton Island (fig. 1) up to 2 million tons of coal worth about $\$ 18$ per ton is mined yearly from workings whose inclined submarine shafts extend as far as 6 miles seaward off the coast.

The only metalliferous area which has exposure close enough to the sea on the United States coast to warrant serious offshore interest is the copper and zinc district in and around Penobscot Bay, Maine (fig. 1). Known workings include the Blue Hill and Black Hawk areas (sphalerite-chalcopyrite) (W. A. Anderson, Maine Geological Survey, oral commun., 1971).

\section{MANGANESE NODULES, PHOSPHORITE, AND OTHER AUTHIGENIC MINERALS FORMED ON OR BELOW THE SEA FLOOR}

Millions of tons of both manganese-iron oxide nodules and phosphorite are known from the Blake Plateau, off the coast between Florida and South Carolina (Pratt and McFarlin, 1966; Manheim and Pratt, 1968; Pratt, 1971). These deposits have been repeatedly investigated by private firms, but their poor grade and the difficulty of recovery under the Gulf Stream at depths of 500 to $1,000 \mathrm{~m}$ relegate them to the status of potential resources for the relatively distant future. Study of the regional geological setting of the phosphorite deposits indicates that the phosphorite-enriched zones were developed in late Oligocene to middle Miocene time along the entire North American continental margin (fig. 7). Economic deposits, such as those in Florida, South Carolina, and North Carolina have been enriched partly by selective leaching and erosion. Residual phosphorite grains often become remobilized or reprecipitated to form slabs, cobbles, crusts and other forms (Cathcart, 1968, and works cited therein).

Normal marine or continental sediments such as shale, sand, and limestone contain less than 0.2 percent $\mathrm{P}_{2} \mathrm{O}_{5}$. Middle Tertiary sediments containing significant phosphate enrichments (more than 1 percent $\mathrm{P}_{2} \mathrm{O}_{5}$ ) extend far north- 
ward, even to the Grand Banks area, and are noted in those areas where Tertiary sediments

are exposed to erosion, such as the shelf break and especially submarine canyons, as well as in

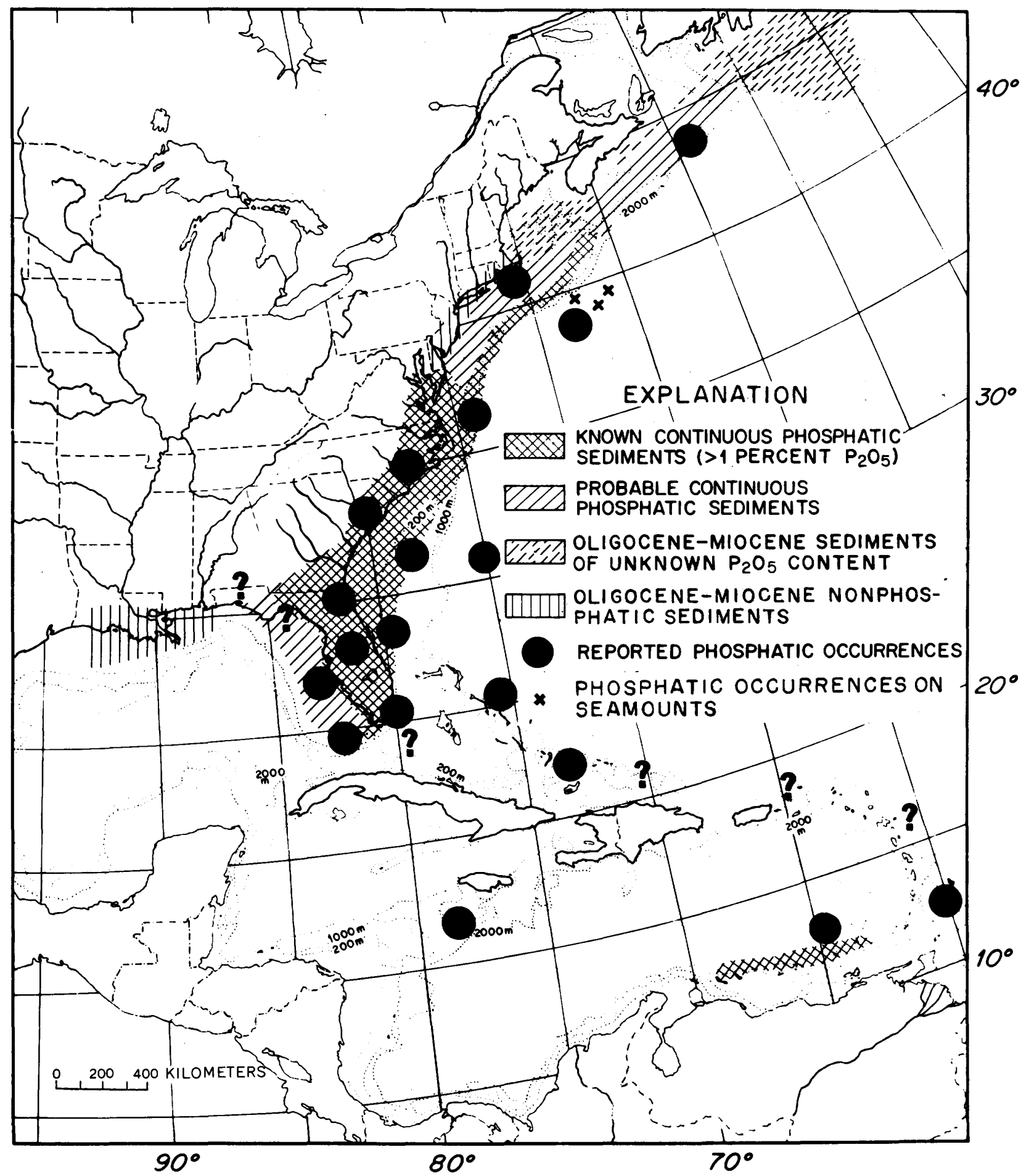

FiguRE 7.-Distribution of middle Tertiary phosphate-bearing sediments along the eastern continental margin of North America (from F. T. Manheim and R. M. Pratt, unpub. data). Queries indicate areas of possible phosphatic sediments. 
recent boreholes in the Canadian offshore region. So far, however, these phosphatic sediments remain of scientific (lithostratigraphic and paleooceanographic) rather than economic interest, as there is little evidence that marked enrichments occur north of Cape Hatteras. Even less is known of the Eocene and Cretaceous phosphorites which are reported from scattered localities on the continental margin.

Of scientific interest are peculiar phosphatic and iron-rich concretions on Georges Bank (Stanley and others, 1967), which appear to be formed from fossil bones, and phosphatic deposits and manganese-iron crusts and nodules on the New England Seamounts (fig. 1) (Uchupi, 1968). The purer manganese iron deposits are found on the farther offshore seamounts, where continuing metal-oxide precipitation is less diluted with ordinary sediments than closer to sources of sediment influx.

\section{DEEPER IN-PLACE ORE DEPOSITS}

As pointed out by Emery (1966) and Uchupi (1966), deeper rocks underlying the Gulf of Maine are to a considerable extent deformed and metamorphosed and are therefore inhospitable for oil or gas. Through geophysical studies which penetrate the blanket of glacial and postglacial sediments, some of the major rock types and structural relationships have been delineated, but the economic potential for metalliferous or other ores is unknown. More intensive study, including shallow core-drilling, needs to be performed before estimates of potential can be made. Because the costs of undersea mining greatly exceed those on land at present, only very substantial deposits could be mined.

Although glaciation normally complicates the geological study of a region, glacial action does provide at least one mechanism which may expose rather than conceal valuable or interesting rock formations. Ice sheets tend to scrape up and disperse fragments of ground-up materials from point sources. Unidirectional glacial action thus tends to form typical fan-shaped residues of material pointing to the source (figs. 8 and 9). In some cases, the distributions of residues of material may reveal bodies or rock formations which would otherwise be overlooked. A large-scale example of dispersion

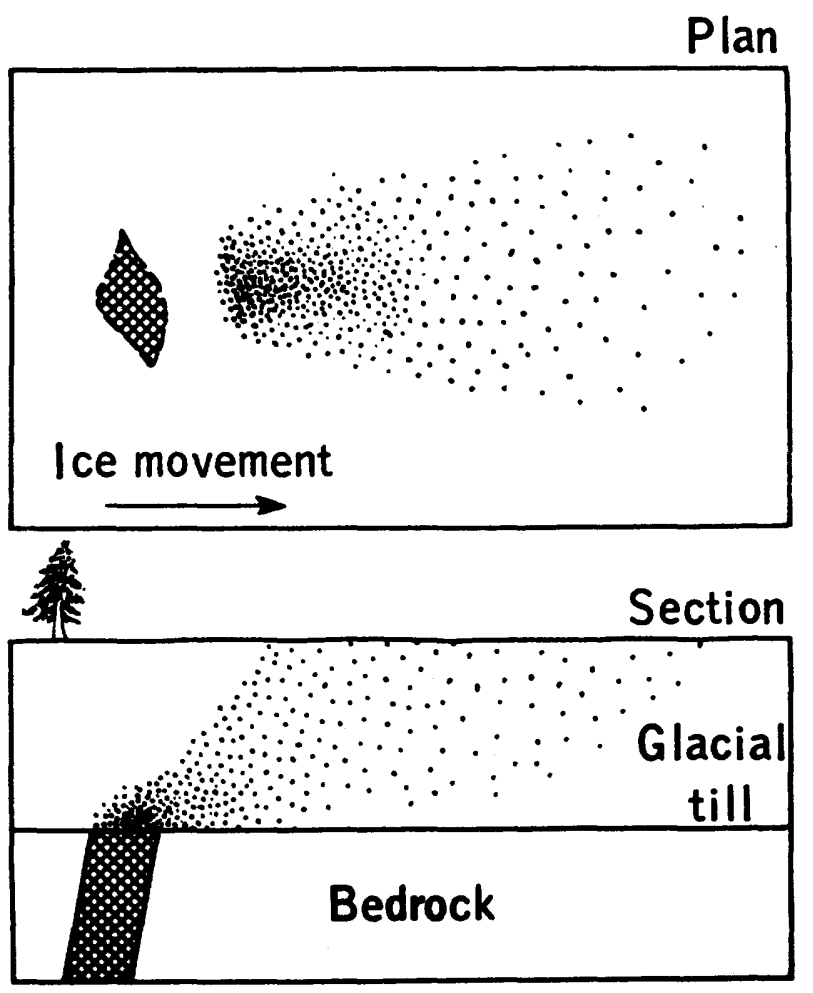

FIGURE 8.-Schematic drawing showing transport of material from outcrop by glacial action (from Hawkes and Webb, 1962, fig. 8-4; reprinted from "Geochemistry In Mineral Exploration" with permission of Harper \& Row, Publishers).

of a given rock material in the Gulf of Maine is shown in figure 10 (Schlee and Pratt, 1970, fig. 16).

\section{SAND, GRAVEL, AND MUD}

As pointed out by Emery (1968), Rexworthy, ${ }^{4}$ Schlee (1968), and Schlee and Pratt (1970), sand and gravel represent not only a very large, but probably the most immediate, resource likely to be exploited on the offshore Atlantic margin of the United States. Offshore sand and gravel production around the United Kingdom now amounts to about 14 million tons per year or 13 percent of total production, and demand and production continue to grow (Hess, 1971).

In the United States, sand and gravel production makes up about one-fifth of the total nonmetallic industry in value, amounting to about

\footnotetext{
${ }^{4}$ S. R. Rexworthy, 1968, The sand and gravel industry of the
United States of America with special reference to exploiting the deposits offshore the eastern seaboard: Unpub. rept. for Ocean Mining Aktiengesell., $48 \mathrm{p}$.
} 


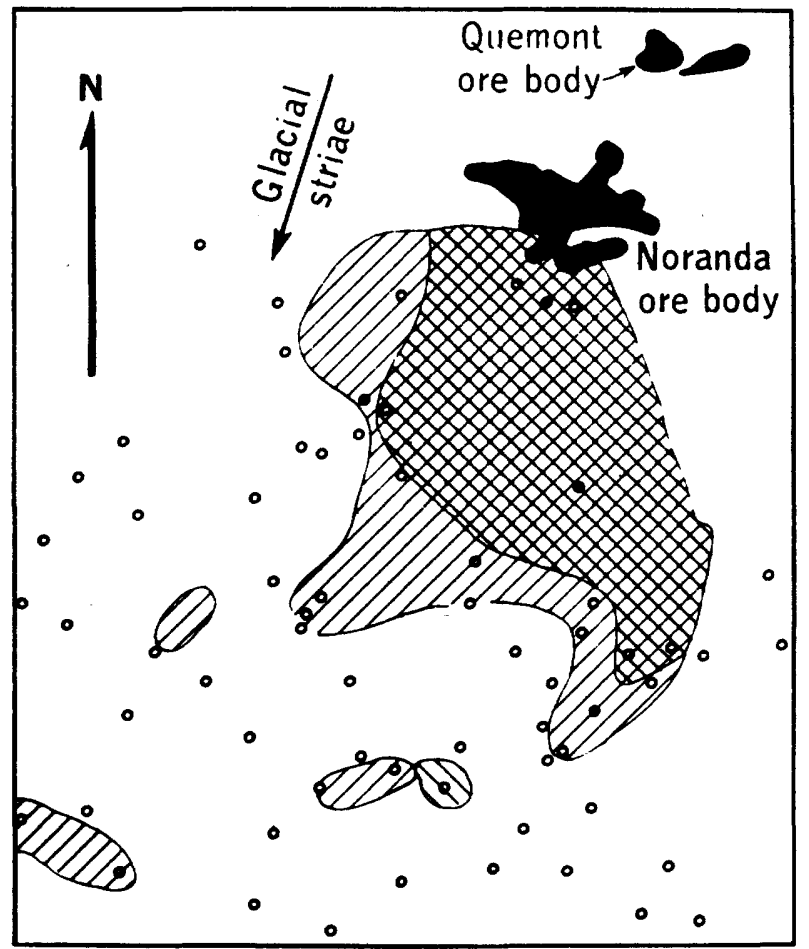

$\square \mathrm{Cu}>75 \mathrm{ppm} \quad \mathrm{Zn}>175 \mathrm{ppm}$

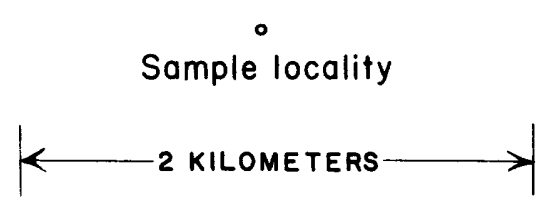

FIGURE 9.-Copper and zinc content of moraine (glacial deposits) near the Noranda ore body, Canada (from Hawkes and Webb, 1962, fig. 10-6; reprinted from "Geochemistry In Mineral Exploration" with permission of Harper \& Row, Publishers).

1 billion tons and about $\$ 1.1$ billion value in 1970. In addition, somewhat less than 1 billion tons of crushed stone and other aggregate competed with sand and gravel for use in building and paving of roads (tables 2 and 3 ).

In spite of the current standstill in offshore leasing or exploration activities preparatory to exploitation (see "Environmental Factors"), several factors combine to exert pressure toward the mining of building aggregates offshore in the near future. Spreading urban areas continue to encroach on or exhaust sand and gravel quarries, which must normally be located close to the major-use sites. This is so because transportation is the principal factor in the cost of sand and gravel. Moreover, restrictions arising from enviromental and esthetic concern, rural zoning, and rise in land values decrease the availability and increase the cost of quarries. This is even more true of hard-rock quarries, which utilize blasting and are regarded as locally undesirable.

Most sand and gravel is used for construction (building and road) purposes, and value and production have increased over the last few decades at about 4 to 5 percent per year, on the average. Cement, prestressed concrete, readymixed concrete, and other special products all depend on constant and convenient supplies of aggregate materials.

Data on sand and gravel production in the United States and some northeastern States for 1970 are given in tables 2 and 3. Telephone inquiries were made in April 1972 to dealers in

TABLE 2.-Quantity and value of sand and gravel production for various uses in the United States in 1970

[Quantity in millions of short tons; value in millions of dollars a point of production. Data from Walter Pajalich, U.S. Bureau of Mines (oral commun., 1972)]

\begin{tabular}{|c|c|c|c|c|}
\hline \multirow[b]{2}{*}{ Use } & \multicolumn{2}{|c|}{ Quantity } & \multicolumn{2}{|c|}{ Value } \\
\hline & Sand & Gravel & Sand & Gravel \\
\hline $\begin{array}{l}\text { Construction: } \\
\text { Building } \\
\text { Paving } \\
\text { Fill } \\
\text { Railroad ballast } \\
\text { Other - }\end{array}$ & $\begin{array}{c}166 \\
139 \\
33 \\
1.2 \\
14.4 \\
\end{array}$ & $\begin{array}{r}130 \\
364 \\
43 \\
2.8 \\
12.4 \\
\end{array}$ & $\begin{array}{r}\$ 198 \\
149 \\
21 \\
16.0 \\
163\end{array}$ & $\begin{array}{r}\$ 191 \\
384 \\
27 \\
2.4 \\
14.6\end{array}$ \\
\hline $\begin{array}{l}\text { Total } \\
\text { Total industrial } \\
\text { use, ground and } \\
\text { unground }\end{array}$ & & 06 & \multicolumn{2}{|r|}{101} \\
\hline $\begin{array}{l}\text { Total, all } \\
\text { purposes } 1\end{array}$ & \multicolumn{2}{|c|}{944} & \multicolumn{2}{|c|}{$\$ 1,116$} \\
\hline
\end{tabular}

1 Data do not add to totals shown because they do not include miscellaneous uses.

TABLE 3.-Quantity and value of sand and gravel and stone produced by some northeastern States, 1970

[Data from Walter Pajalich (sand and gravel) and H. J. Drake (stone) of the U.S. Bureau of Mines (oral commun., 1972). Where data for 1970 are unavailable, data for 1969 (U.S. Bureau Where data for 1970 are unavailable, data for 1969 (U.S. Bureau of Mines, $1971, p, 1027$ ) are given in parentheses. Quantity in
millions of short tons; value in millions of dollars. W, withheld to avoid disclosing individual company data]

\begin{tabular}{|c|c|c|c|c|}
\hline \multirow[b]{2}{*}{ State } & \multicolumn{2}{|c|}{ Sand and gravel } & \multicolumn{2}{|c|}{ Stone } \\
\hline & Quantity & Value & Quantity & Value \\
\hline Maine & 13.0 & $\$ 6.9$ & 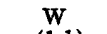 & $1 \$ 2.3$ \\
\hline New Hampshire --- & -6.5 & $\overline{4} .8$ & $\stackrel{1}{\mathbf{W}}$ & 1.845 \\
\hline $\begin{array}{l}\text { Massachusetts } \\
\text { Rhode Island }\end{array}$ & $\begin{array}{r}\overline{17} .9 \\
2.4\end{array}$ & $\overline{22.2}$ & W & W \\
\hline $\begin{array}{l}\text { Connecticut } \\
\text { New York } \\
\text { New Jersey }\end{array}$ & $\begin{array}{r}-6.8 \\
35.5 \\
16.7\end{array}$ & $\begin{array}{r}-\overline{9} .2 \\
38.8 \\
31.6\end{array}$ & $\begin{array}{r}(w) \\
8.3 \\
37.6 \\
15.2\end{array}$ & $\begin{array}{l}(1.4) \\
16.9 \\
68.1 \\
40.6\end{array}$ \\
\hline
\end{tabular}

1 State total incomplete to avoid disclosing individual company data. 


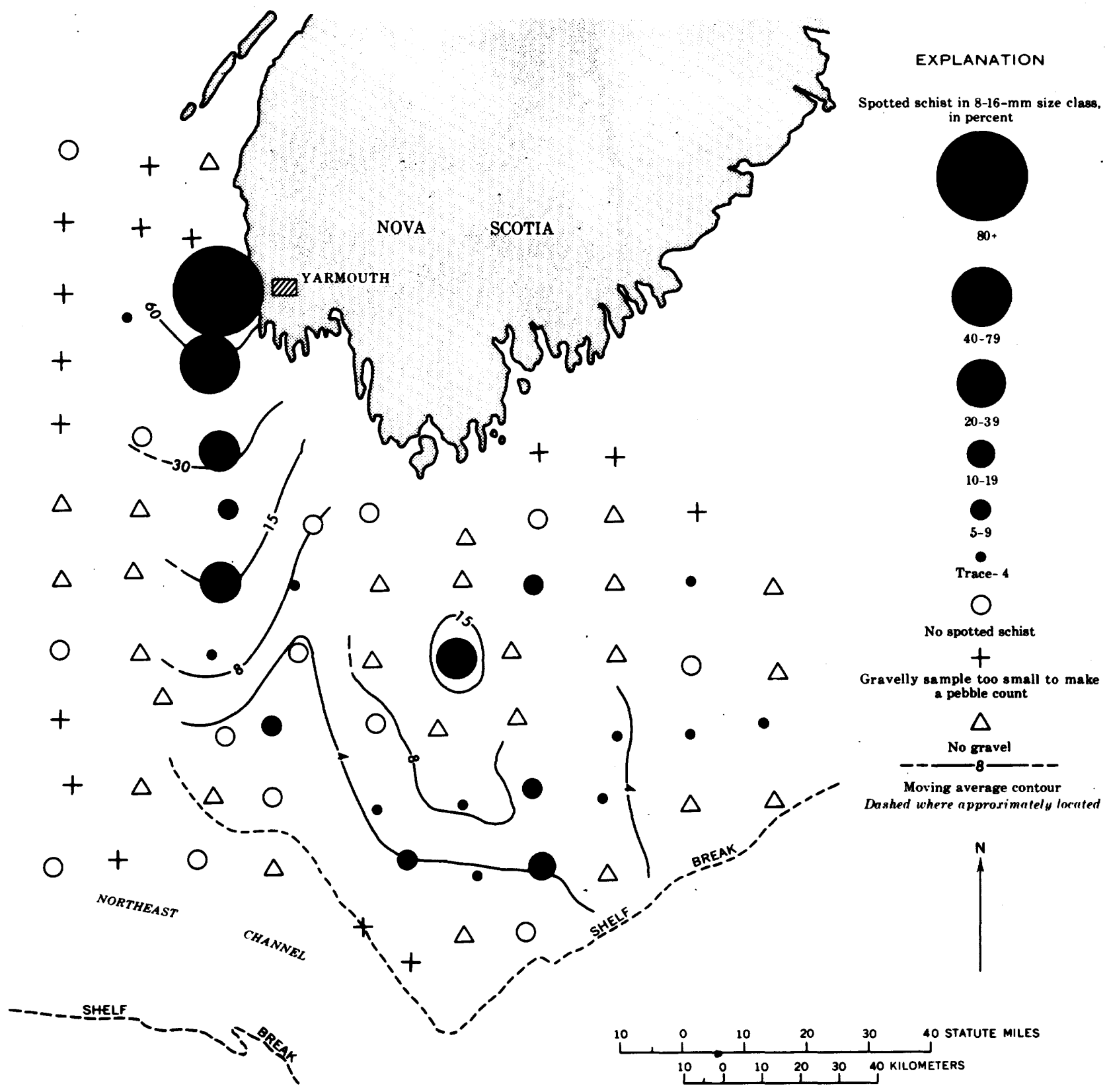

FIGURE 10.-Distribution and abundance of spotted schist pebbles (8-16-mm size class) in gravels on the southeastern Scotian Shelf. Computed by moving-average technique (from Schlee and Pratt, 1970, fig. 16).

major east coast centers to obtain the price of sand (concrete quality) and gravel. Prices were quoted f.o.b. plant. Some of the sand and gravel pits are at a considerable distance from the metropolitan areas. The following prices (per short ton) vary relatively little from 1971 prices: Boston, sand $\$ 2.00$, gravel $\$ 3.00$; New York, sand $\$ 0.75$ at plants in southern New Jersey to $\$ 1.50$, gravel $\$ 3.00$; Philadelphia, sand $\$ 1.35$ ( $\$ 3.50$ delivered; transport cost about $\$ 0.40$ per ton mile), crushed stone $\$ 3.50$; Washington, D.C., sand $\$ 2.75$, gravel, truck loads $\$ 3.50$, larger quantities $\$ 3.00$. Production for New York and New Jersey slumped in 1969-70 owing partly to a decline in supplies but largely because of a decrease in construction activities in the greater New York City area. The latter factor probably accounts for 


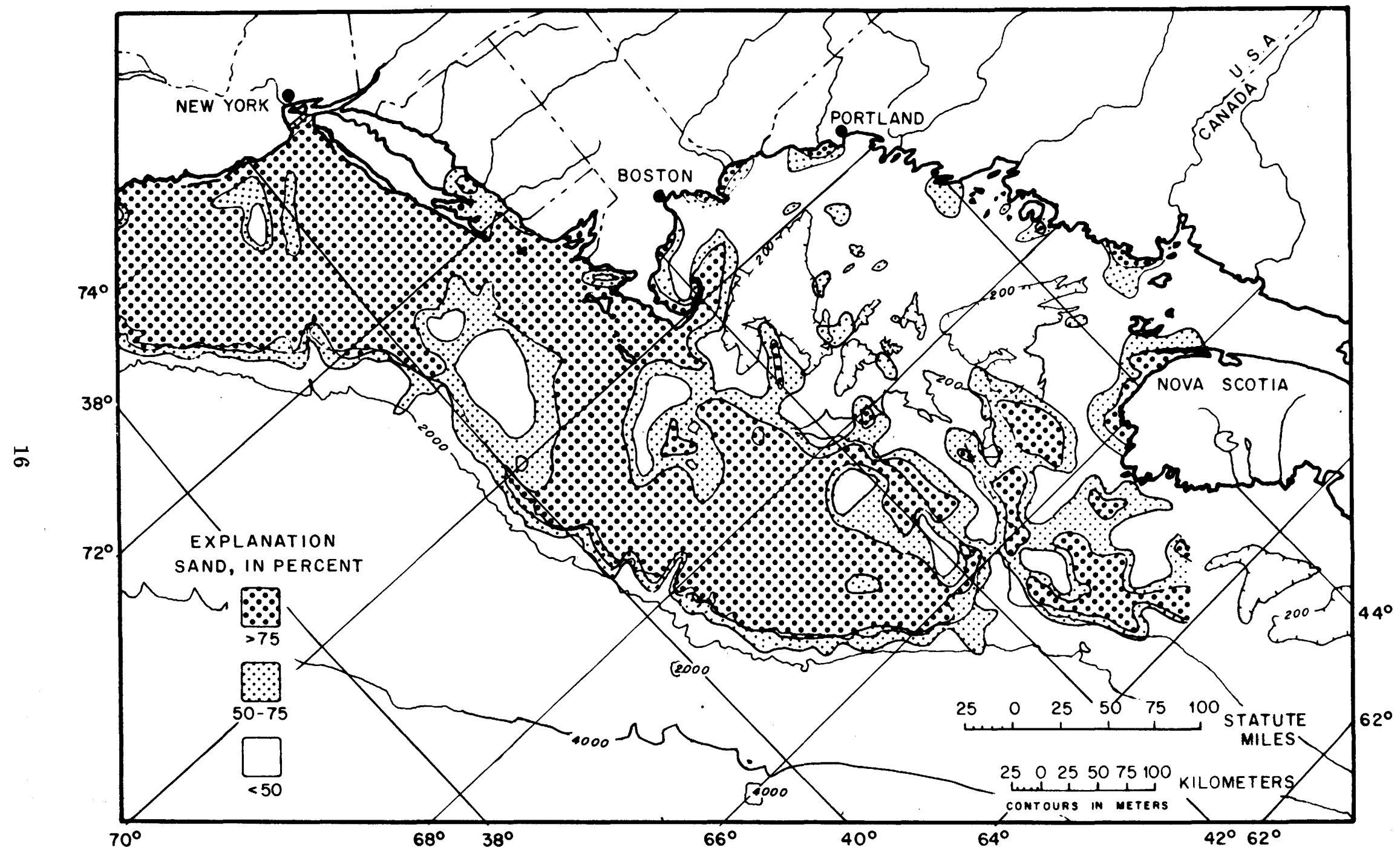

FIGURE 11.-Distribution of sand on the continental margin off Northeastern United States (redrawn from Schlee and Pratt, 1970, pl. 5A). 
the low prevailing prices in this area.

Existing sand deposits on the shelf are very large (fig. 11). In the area shown in figure 11, surficial sand deposits grading 75 percent or more cover $112,000 \mathrm{~km}^{2}$. One can get an idea of the sand resources contained in this area by assuming a dredging depth of $3 \mathrm{~m} \mathrm{(10} \mathrm{ft)} \mathrm{and}$ 50 percent porosity ( 1.35 tons of dry sand per cubic meter of wet sediment). The total of about 450 billion tons of dry sand obtained is enough at current consumption rates to meet the needs of all the northeastern coastal states of the United States and the Maritime Provinces of Canada for several thousand years. Though poorly known at present, actual thicknesses are probably at least 10 times greater. Drill cores will be required to establish depths and characteristics of the sand.

A few sand deposits, such as those off New Jersey (fig. 12) (Schlee, 1964), have been

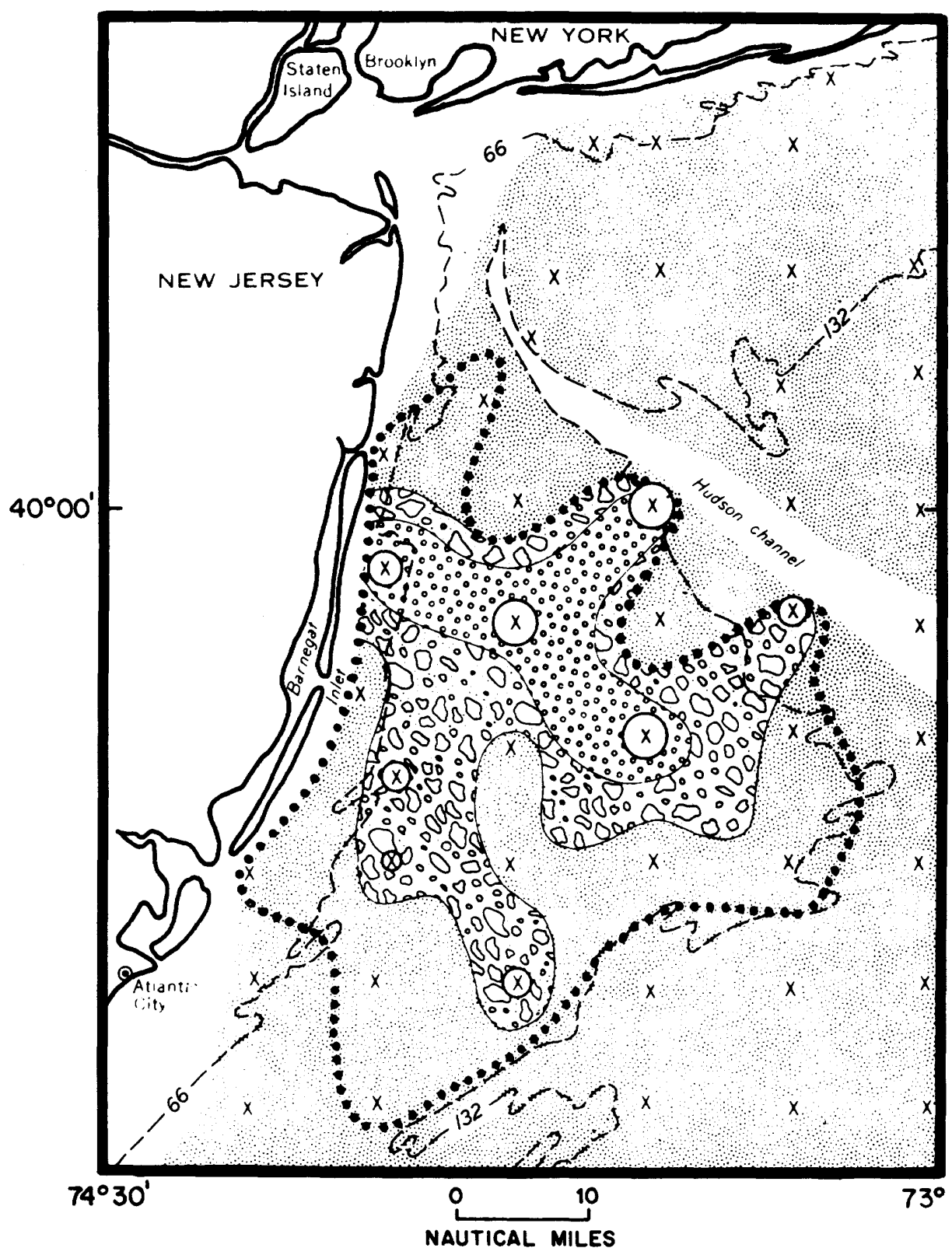

\section{EXPLANATION} $x$

SAMPLE LOCATION
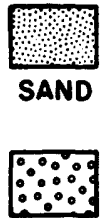

SANDY GRAVEL

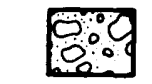

pebBly sano

MAXIMUM PEBBLE SIZE

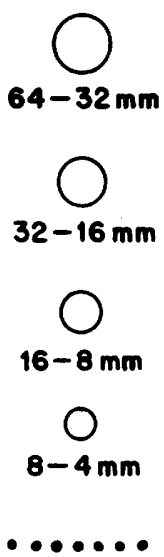

BOUNDARY OF LIMONITESTAINED SEDIMENT

$--66--$

SUBMARINE CONTOUR SHOWING DEPTH IN FEET

Figure 12.-Distribution of sand and gravel off New Jersey (from Schlee, 1964). 
sufficiently well delineated to indicate their direct suitability for immediate exploitation. Leases have been requested, but activities await promulgation of clear regulatory guidelines by State and Federal agencies. Other sand supplies north of Cape Cod also offer clear potential (fig. 13). Another prime target for dredging, though farther offshore, is Nantucket Shoals, which has been a major hazard to navigation, as attested to by the hundreds of wrecks still located there.

Gravels are much less abundant than sands on the shelf and generally would require longer transport to consumer areas (figs. 14 and 15). However, gravels have greater value and, as has been pointed out by recent lively discussions on the question of offshore sand and gravel mining (Davenport, 1971; Taney, 1971), distance is a much less important factor at sea than on land. Whereas the capital costs to initiate viable commercial dredging operations offshore are much higher than on land, say on the order of $\$ 5$ million dollars, the barging and delivery of materials to coastal urban centers is much less costly than trucking (main land means) or even rail. With efficient technology and good organization, there seems little doubt that major centers could begin to utilize seafloor aggregates within the next 5 or 10 years.

Sediments containing more than 50 percent gravel cover about $15,000 \mathrm{~km}^{2}$ in the area shown in figure 14. In the smaller area in figure 15, presumably a potential supplier to the Greater Boston and Massachusetts shore communities, sediments containing more than 60 percent gravel cover $345 \mathrm{~km}^{2}$, which, under assumptions previously made for sand dredging, would yield 1.4 billion tons.

In the United Kingdom, subsidies of about 20 percent of costs were offered earlier to stimulate building of offshore dredging equipment, but these have been discontinued as no longer necessary (Hess, 1971). Private surveys of conditions in the United States also indicate that subsidy of offshore sand and gravel production would not be needed, given a stable and appropriate legal climate.

Sand and gravel are not the only potentially valuable sediments in the offshore bottoms. The natural grading of materials by grain size and mineralogic and chemical compositions offers a wide range of earth materials which might find uses through technologic innovations. A recent discovery (patent pending) by D. C. Rhoads, R. B. Gordon, and M. A. Ruggiero (Bingham Laboratory, Yale University, New Haven, Conn.) is that ceramic material of superior quality can be made by firing fine marine sediment that contains less than 10 percent calcium carbonate and between 1 and 3 percent organic matter. Advantages of the marine material are that it need not be subjected to complex blending processes involving different raw material sources, it can be obtained in very large volumes by simple surface dredging of deposits in Long Island Sound, Buzzards Bay, and other areas along the northeast continental margin, and it has much lighter finished weight than brick or other comparable ceramics. Channel dredging materials may be suitable, as may be muds in contaminated bays or tidal water bodies, for the excess organic carbon attributable to pollution products actually promotes favorable attributes in the finished ceramic; the gases released on firing create high porosity and therefore lightness. The sea salt incorporated in the raw mud also aids in the fluxing of the ceramic to create desirable strength and other properties. One may point out that muddy basins where the indicated materials occur (fig. 16) are generally poor fishing grounds and otherwise play a subordinate role in the marine biologic cycle offshore, insofar as present information permits assessment. Under certain conditions, removal and use of the mud from polluted areas, such as inner Long Island Sound (Gross and others, 1971), may actually improve the local aquatic habitat much more rapidly than could be done by the slow process of natural deeutrophication after the input of pollutants is stopped. This kind of innovative and coordinated use of offshore resources needs especial encouragement and stimulation.

\section{ENVIRONMENTAL FACTORS}

Shelf sands and gravels are metastable deposits on the northeastern continental margin and are undergoing erosion and winnowing by natural forces such as bottom currents. In contrast to widespread impressions to the contrary, 


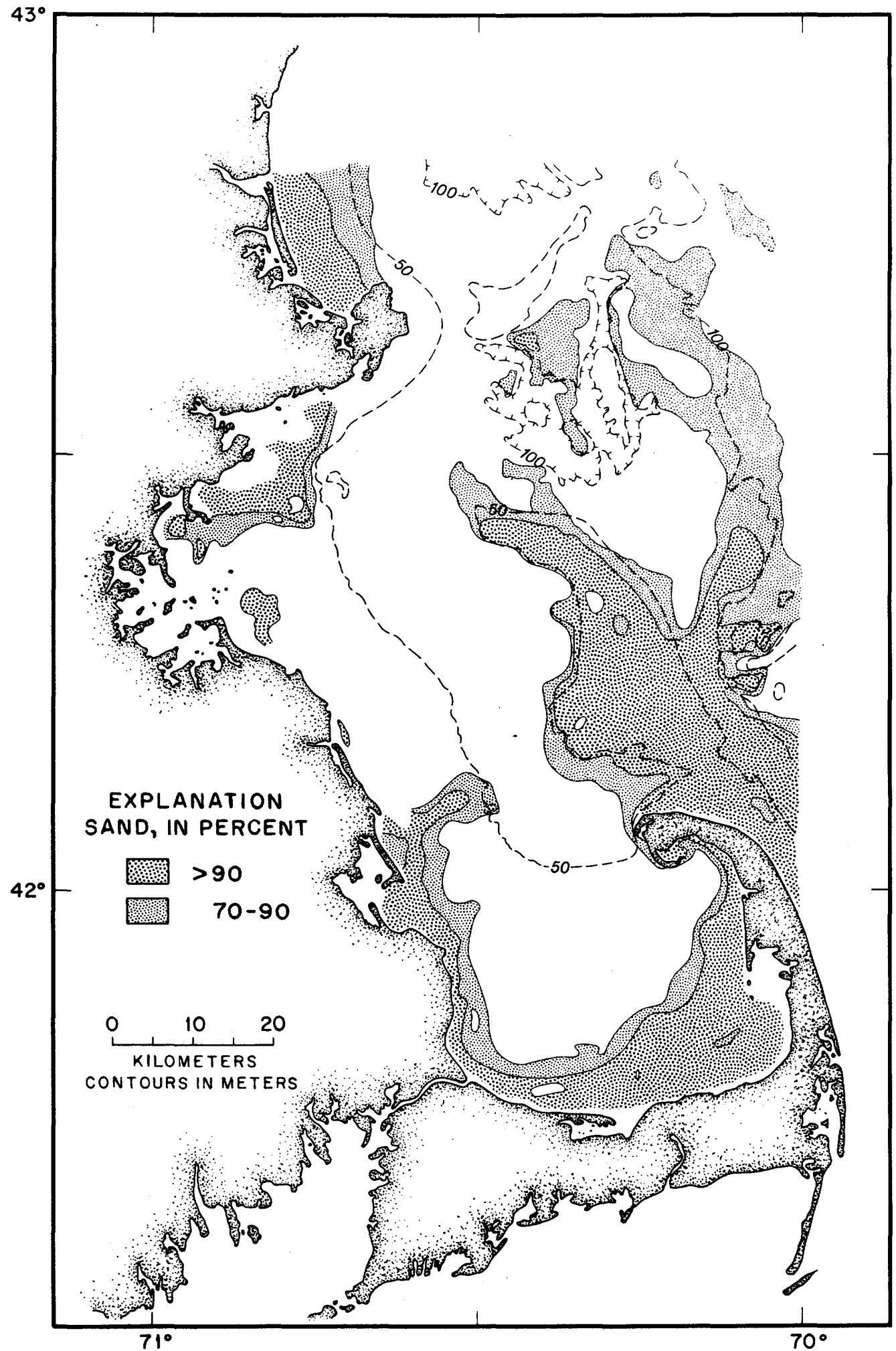

Figure 13.-Distribution of sand in the inner Gulf of Maine and Massachusetts Bay (redrawn from Schlee and others, 1971). 


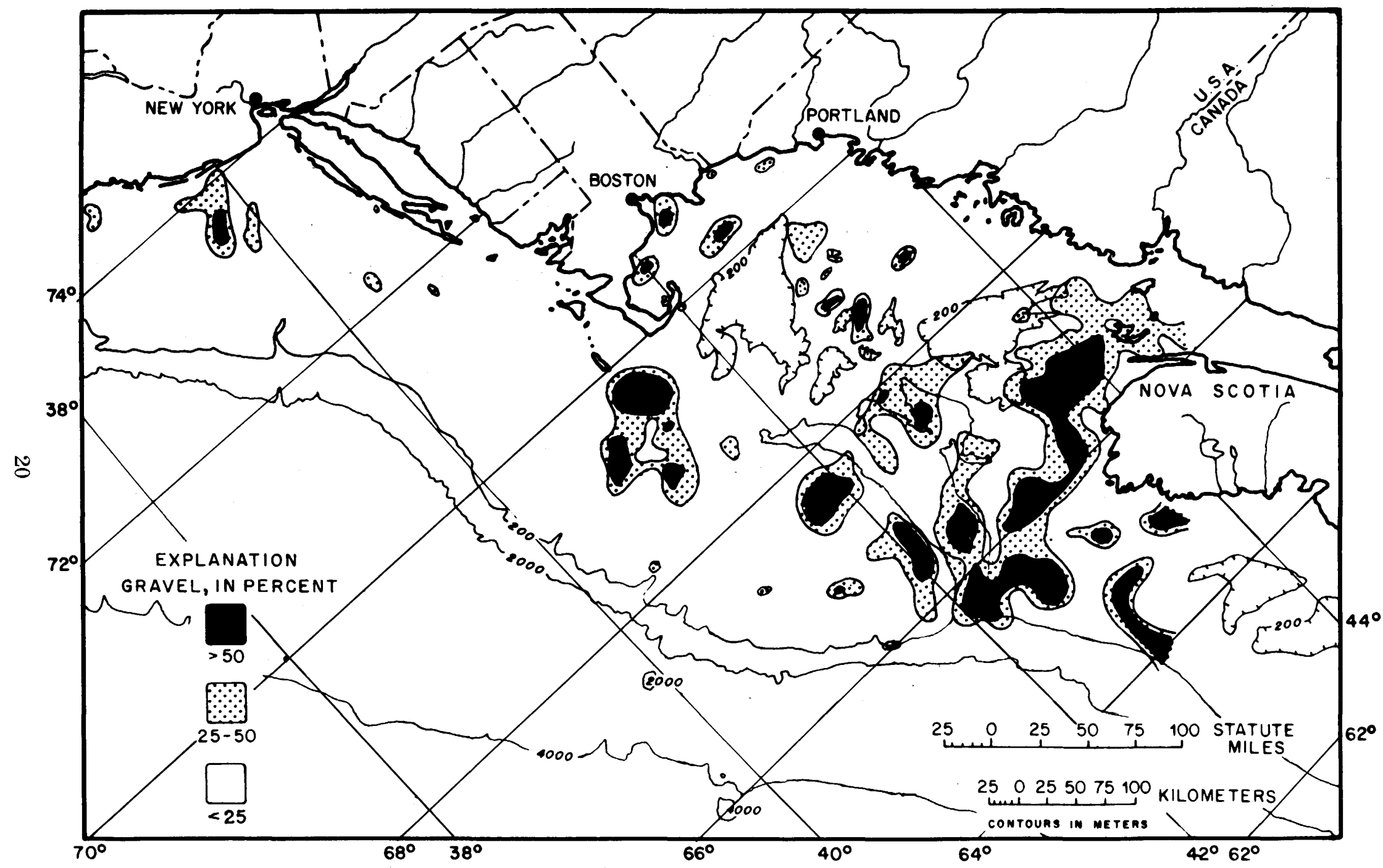

FiguRe 14.-Distribution of gravel on the continental margin off Northeastern United States (redrawn from Schlee and Pratt, 1970, pl. 5B). 


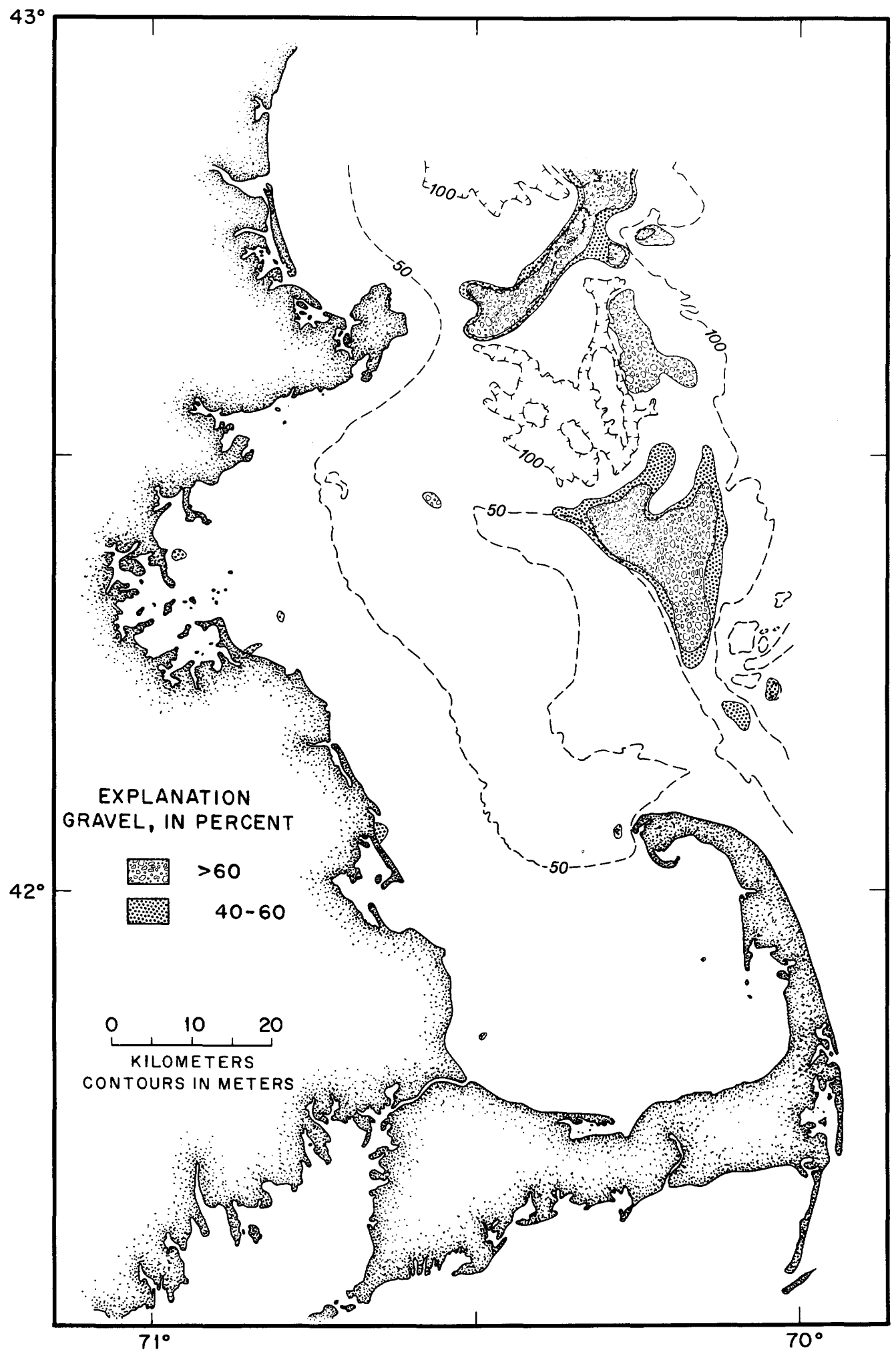

Figure 15.-Distribution of gravel in the inner Gulf of Maine and Massachusetts Bay (redrawn from Schlee and others, 1971). 


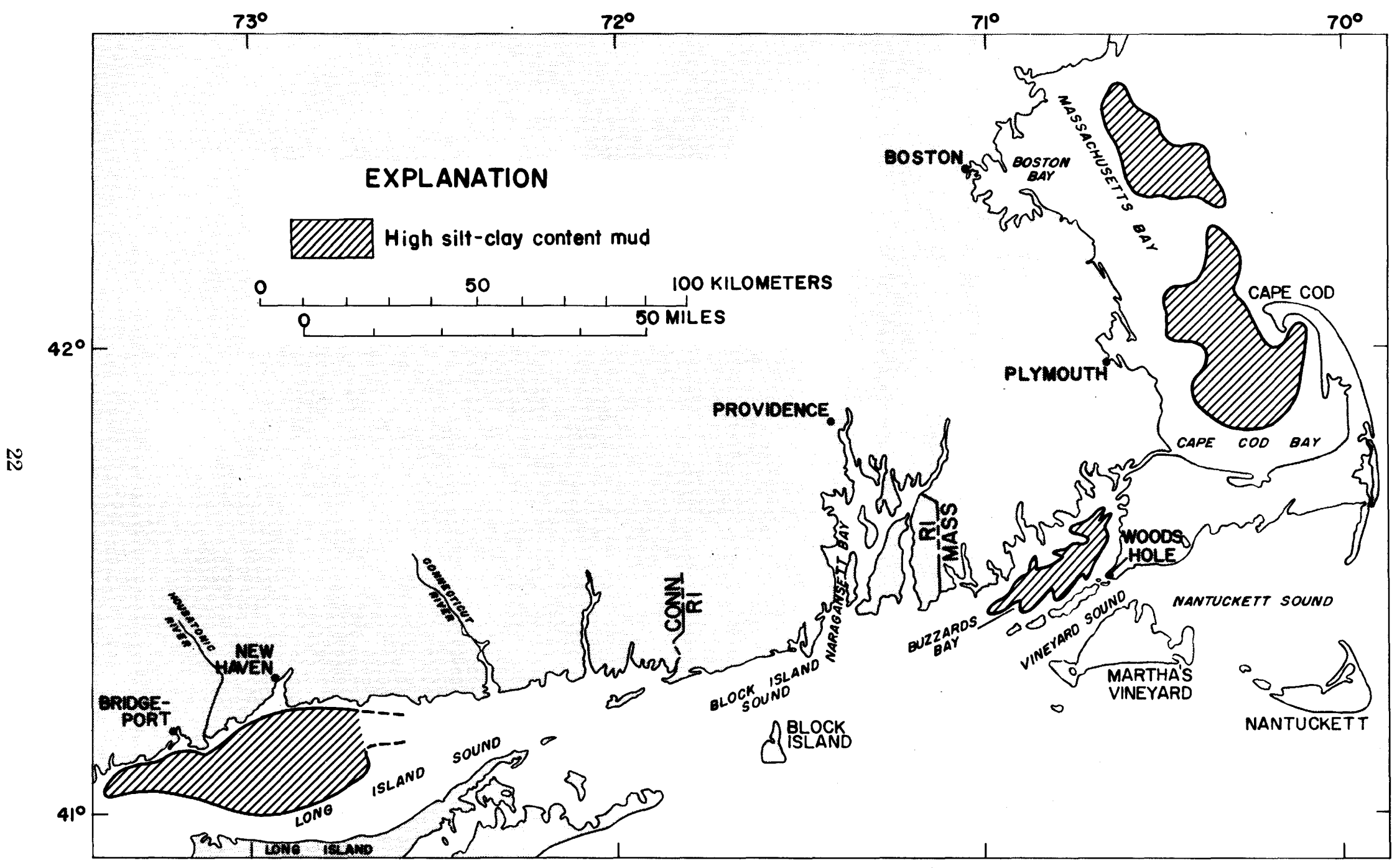

FIGURE 16.-Offshore distribution of sediments that can be used in an innovative ceramic manufacturing process. 
most estuaries on the continental margin may not have a net loss of sediment to the shelf and open ocean; rather, sediment moving into the estuaries by bottom transport from the shelf is tending to fill them up on a net basis (fig. 17A) even though outward transport of river sediments does take place at the same time (Meade, 1969). Thus, the dredging of a harbor mouth, as in the case of Savannah Harbor, has not increased outward loss of sediment, but rather has accelerated the silting up to the harbor, because movement of bottom material inward is facilitated (H. B. Simmons, cited in Meade, 1969). From this point of view, mining of offshore sands may be taking materials which are tending to move into the continent in any event (fig. 17B).

A different problem is posed by beach and shore erosion. Whether or not the taking of sand from one area might promote erosion in another coastal zone must be assessed separately for each case. On the one hand, experience in the United Kingdom, where offshore sand and gravel have been mined since World War II, has brought to light only a few cases where coastal erosion has been attributed to sand mining, and these occurred where the mining was in relatively close proximity to the affected shore. On the other hand, studies of actual movement of bottom materials in the Atlantic offshore region are still very limited. Moreover, though the data are still inadequate, it can be shown qualitatively that storms and hurricanes have a much greater influence on beach erosion and coastal modification in many areas than day to day action (Hayes, 1967; Coastal Plains Center for Marine Development Services, 1970, and publications cited therein). Thus, there will continue to be coastal erosion with or without mining operations.

Marine life is potentially affected by marine mining and other activities that modify sediments. For example, Massachusetts oyster production has declined from 24 million pounds (meat) annual production in 1910 to only a few tens of thousands of pounds per year in recent years. Discussion with officials of the Massachusetts Department of Natural Resources and other observers indicates that the major causes of the destruction of oyster fisheries include dredge and fill operations and no or inadequate management of oyster beds in the public (that is, town) domain: For example, in some places oysters are taken without returning the shell to provide cultch or other hard surfaces needed by oyster spat as substrates. Marine biologists familiar with shelf fauna and flora indicate that mining operations on the shelf are not inherently incompatible with proper maintenance of marine life and commercial and sports fisheries. However, they indicate that proper design of operations and coordination with fisheries authorities are important factors in assuring ecologically judicious development. For example, mining operations might be shifted to different areas according to seasons of the year, in order to avoid the spawning grounds of given fish species.

A serious problem at present is the expanding pressure on existing sites for dumping of dredge spoils. For example, dredgings in Delaware Bay amounted to nearly 20 million cubic yards per year until a few years ago, when damming off of the spoils reduced the need for dredging to about 10 million cubic yards per year. However, in the foreseeable future all available dumping space will be exhausted if dumping is not to be done where environmental damage will result or where exorbitant transport costs are incurred. Extracts from the earlier U.S. Commission on Marine Science, Engineering and Resources (Coastal Research Notes, 1971) indicated that the draft requirements of the new super tankers (up to $70 \mathrm{ft}$ ) are so great that in some areas channels extending as much as 60 miles from shore or deep-water terminals would be needed to accommodate the vessels. Even medium-sized super tankers cannot be accommodated by any present-day Atlantic ports. Alternatives to dredging may not be simple or cheap because they involve the possibility of declining port usage and the necessity of supplying energy and essential fuels by other means. According to the reports, dredgings even at current rates would fill most currently available disposal sites in 8 to 10 years.

If innovative and efficient technological means could be found to utilize dredge spoils to supply aggregate needs (other than fill), then a dual advantage would be gained; the destruction of land areas for sand and gravel mining purposes 


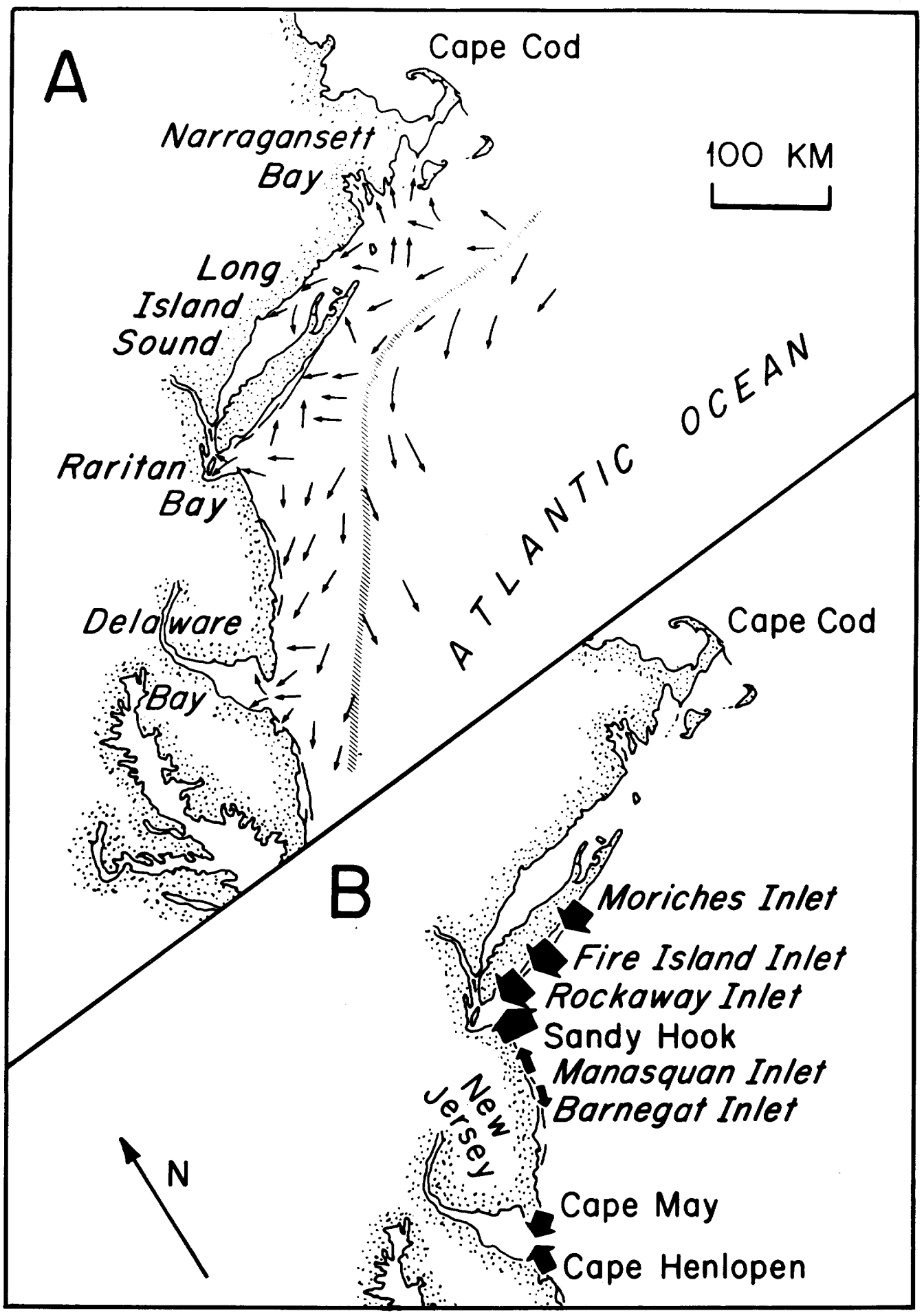


which has promise in this direction. The approximate regional balance of dredge spoils and sand and gravel consumption is shown in figure 18.

Innovative use of offshore bottoms might even improve the aquatic or biologic environment under certain conditions. An example of the "surgical removal" and utilization of polluted mud has already been mentioned. D. C. Rhoads (oral commun., 1971) has also pointed out that mud bottoms (especially if they are highly organic owing to deposition of sewage or other organic matter of primary or secondary origin) might serve as sources of food to nourish an intensive above-bottom aquaculture (for example, mussels, clams, oysters). Freed from predators, and with good substrates provided, the organisms could use excess organic matter and nutrients not only to produce marketable protein, but help deeutrophicate previously contaminated basins. Pilot studies for analogous types of aquaculture are being carried on by J. H. Ryther and his coworkers at the Woods Hole Oceanographic Institution.

The history of the Atlantic offshore region shows that we are now at a crossroads. Before, when mining leases could have been obtained at nominal cost, there was little incentive to prospect offshore. Now, when the growth of coastal populations and increased demand for products potentially available from the sea bottom renders such exploration and exploitation attractive, there is virtually a complete moratorium on leasing while State, Federal, and local regulatory agencies reassess their operations procedures in response to the growth in environmental concern, as well as improved knowledge of the natural environment itself.

Massachusetts, for example, has recently enacted a moratorium on all offshore leasing within the State boundaries (Mass. Sen. 737, Ch. 567,
1971), and another bill (Sen. 1445, Ch. 742, 1971) provides a natural sanctuary around the entire Cape Cod region, stipulating that no dredging or dumping of whatever kind may be performed, except for beach restoration purposes. The legislature has also allocated $\$ 200,000$ to the Department of Natural Resources to study the environmental aspects of the Massachusetts offshore region with a view to preparing guidelines for leasing when and if the Department deems that offshore exploitation can safely be carried out.

Keys to proper and environmentally judicious management of offshore resources lie in improving presently uncertain or overlapping jurisdiction and coordination and effectiveness of investigatory and regulatory bodies. With limited resources, regulatory bodies must have broad knowledge or access to expertise in many overlapping fields: marine biology, geology, engineering practice, economics, law, politics, and psychology. A short account and bibliography of problems potentially affecting marine mining is provided by McKelvey, Tracey, Stoertz, and Vedder (1969) and Battelle Memorial Institute Staff (1971), respectively.

If regulation is inadequate, damage or public loss of confidence leading to prohibitory legislation or crippling litigation may result. If regulation is unnecessarily rigid or if its inadequacy leads to blanket prohibition, needed and useful goods and services may be denied the public, or unfavorable environmental developments may occur by default. It is often pointed out that offshore work requires adequate capital, technology, and organization; responsible organizations possessing these prerequisites will hesitate to take political risks over and above the usual economic risks involved in new ventures. They need dependable guidelines under which to work.

Figure 17 (left).-Directions of general residual current (A) along the bottom on the continental shelf (from Bumpus, 1965), and (B) directions and magnitudes of sand movement on the beaches (from Meade, 1969, fig. 9 ; reprinted from "Journal of Sedimentary Petrology" with permission of Society of Economic Paleontologists and Mineralogists). Width of arrow shaft in part B indicates estimated amounts of sand; the widest represents about $370,000 \mathrm{~m}^{3}$ per year. 


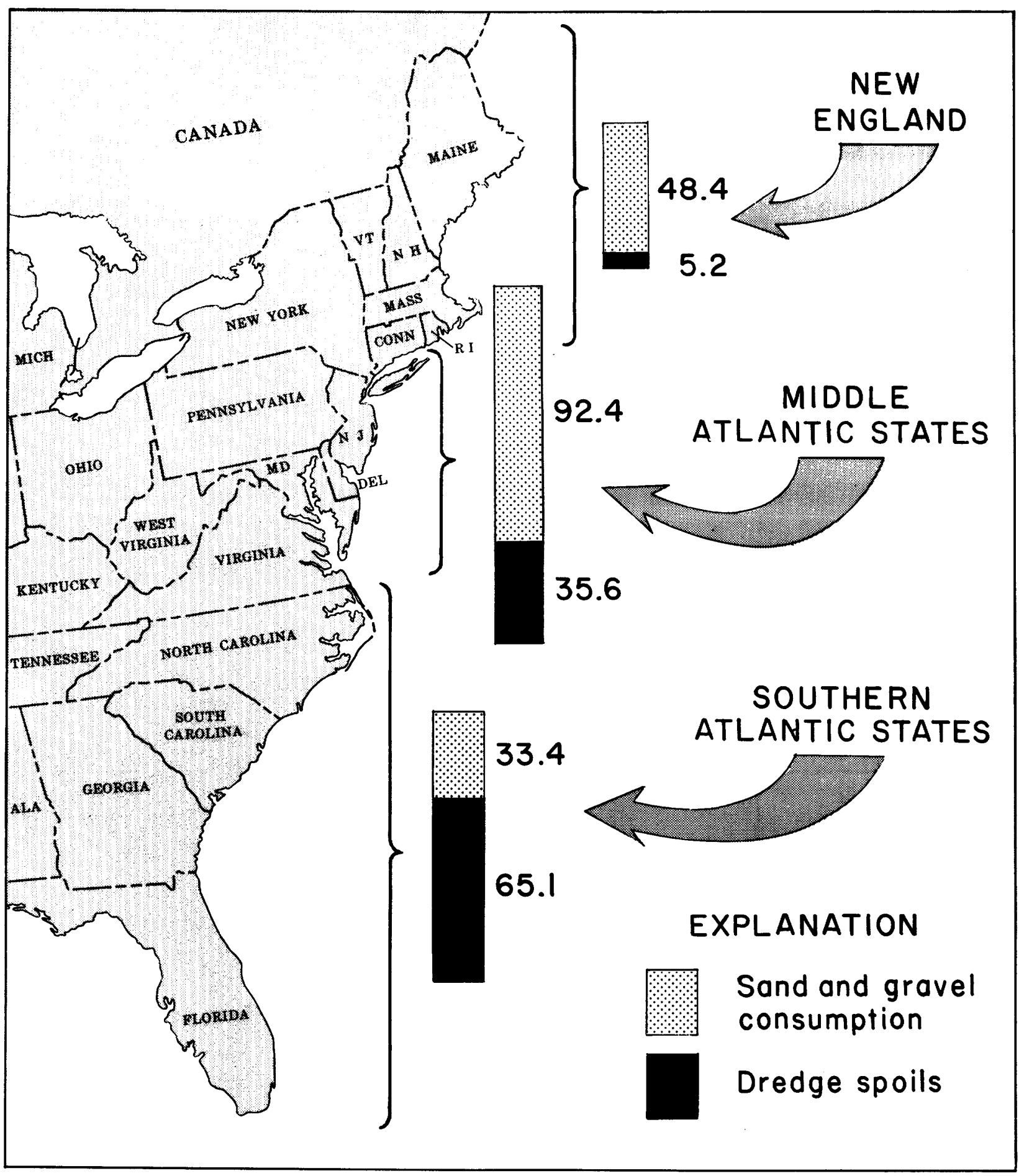

FIGURE 18.-Balance of dredge spoil and consumption of sand and gravel (in millions of tons) in Atlantic Coast States. Dredge spoil data from V. L. Andreliunas, U.S. Army Corps of Engineers (oral commun., 1972) refers to 1971 dredging in and around navigable waterways. Sand and gravel consumption from U.S. Bureau of Mines (1969, p. 986-987). 


\section{REFERENCES CITED}

Battelle Memorial Institute Staff, 1971, Environmental disturbances of concern to marine mining research, a selected annotated bibliography: U.S. Natl. Oceanic and Atmospheric Adm. Tech. Memo. ERL MMTC-3, $72 \mathrm{p}$.

Bumpus, D. F., 1965, Residual drift along the bottom on the continental shelf in the Middle Atlantic Bight area: Limnology and Oceanography, v. 10, supp. (Redfield Volume), p. R50-R53.

Canada Geological Survey, 1949, Geologic map of the Maritime Provinces (New Brunswick, Nova Scotia, and Prince Edward Island): Canada Geol. Survey Map 910A.

Cathcart, J. B., 1968, Phosphate in the Atlantic and Gulf Coastal Plains, in Forum on geology of industrial minerals, 4th, Austin, Tex., 1968, Proceedings: Austin, Texas Univ. Bur. Econ. Geology, p. 23-24.

Coastal Plains Center for Marine Development Services, Washington, D.C., 1970, Bibliography on hurricanes and severe storms of the coastal plains region: Coastal Plains Center Marine Devel. Services Pub. 70-2, $71 \mathrm{p}$.

Coastal Research Notes, 1971 , [On port-dredging problems] : Coastal Research Notes, v. 3, no. 6, p. 3.

Davenport, J. M., 1971, Incentives for ocean mining: a case study of sand and gravel: Marine Technology Soc. Jour., v. 5, p. 35-40.

Duane, D. B., 1969, A study of New Jersey and northern New England coastal waters: Shore and Beach, v. 37 , no. 2 , p. $12-16$.

Emery, K. O., 1966, Geological methods for locating mineral deposits on the ocean floor, in Exploiting the ocean: Marine Technology Soc. Conf. and Exhibit, 2d Ann., 1966, Trans., p. 24-43.

- 1968, The continental shelf and its mineral resources, in Selected papers from the Governor's Conference on Oceanography, New York, 1967: [Albany, New York State Dept. Commerce] p. 3651.

Emery, K. O., and Noakes, L. C., 1968, Economic placer deposits of the continental shelf: U.N. Econ. Comm. Asia Far East Comm. Coord. Joint Prosp. Mineral Resources Asian Offshore Areas Tech. Bull., v. 1, p. 95-111.

Emery, K. O., Uchupi, Elazar, Phillips, J. D., Bowin, C. O., Bunce, E. T., and Knott, S. T., 1970, Continental rise off eastern North America: Am. Assoc. Petroleum Geologists Bull., v. 54, p. 44-108.

Goldsmith, Richard, 1964, Geologic map of New England: U.S. Geol. Survey open-file rept., 3 sheets, scale $1: 1,000,000$.

Gross, M. G., Black, J. A., Schramel, R. J., and Smith, R. N., 1971, Survey of marine waste deposits, New York Metropolitan region: New York State Univ., Stony Brook, Marine Sci. Research Center Tech. Rept. 8, 72 p.
Hathaway, J. C., 1971, Data File, Continental Margin Program, Atlantic Coast of the United States, Volume 2, Sample collection and analytical data: Woods Hole Oceanog. Inst. Ref. 71-15, 496 p.

Hawkes, H. E., and Webb, J. S., 1962, Geochemistry in mineral exploration: New York, Harper and Row, Publishers, $415 \mathrm{p}$.

Hayes, M. O., 1967, Hurricanes as geological, agents, south Texas coast: Am. Assoc. Petroleum Geologists Bull., v. 51, no. 6, p. 937-942.

Hess, H. D., 1971, Marine sand and gravel mining industry of the United Kingdom: U.S. Natl. Oceanic and Atmospheric Adm. Tech. Rept. ERL 213-MMTC 1, 176 p.

Hülsemann, Jobst, 1967, The continental margin off the Atlantic coast of the United States; carbonate in sediments, Nova Scotia to Hudson Canyon: Sedimentology, v. 8, p. 121-145.

Libby, F., 1969, Searching for alluvial gold deposits off Nova Scotia: Ocean Industry, v. 4, no. 1, p. 4347.

Maher, J. C., 1971, Geologic framework and petroleum potential of the Atlantic Coastal Plain and continental margin: U.S. Geol. Survey Prof. Paper 659, $98 \mathrm{p} ., 17 \mathrm{pls}$.

Manheim,. F. T., and Pratt, R. M., 1968, Geochemistry of manganese-phosphorite deposits on the Blake Plateau, in Woods Hole Oceanographic Institution Summary of investigations in 1967: Woods Hole Oceanog. Inst. Ref. 68-32, p. 49.

McKelvey, V. E., Tracey, J. I., Jr., Stoertz, G. E., and Vedder, J. G., 1969, Subsea mineral resources and problems related to their development: U.S. Geol. Survey Circ. 619, $26 \mathrm{p}$.

McKelvey, V. E., and Wang, F. F. W., 1969, World subsea mineral resources: U.S. Geol. Survey Misc. Geol. Inv. Map I-632.

Meade, R. M., 1969, Landward transport of bottom sediments in estuaries of the Atlantic Coastal Plain: Jour. Sedimentary Petrology, v. 39, no. 1, p. 222-234.

Pratt, R. M., 1971, Lithology of rocks dredged from the Blake Plateau: Southeastern Geology, v. 13, p. 1938.

Pratt, R. M., and McFarlin, P. F., 1966, Manganese pavements on the Blake Plateau: Science, v. 151, p. 1080-1082.

Ross, D. A., 1970, Atlantic continental shelf and slope of the United States-Heavy minerals of the continental margin from southern Nova Scotia to northern New Jersey: U.S. Geol. Survey Prof. Paper 529-G, 40 p.

Schlee, John, 1964, New Jersey offshore gravel deposit: Pit and Quarry, v. 57, p. 80-81.

- 1968, Sand and gravel on the continental shelf off the northeastern United States: U.S. Geol. Survey Circ. 602, 9 p.

Schlee, John, Folger, D. W., and O'Hara, C. J., 1971, Bottom sediments on the continental shelf of the 
northeastern United States, Cape Cod to Cape Ann, Massachusetts: U.S. Geol. Survey open-file rept.

Schlee, John, and Pratt, R. M., 1970, Atlantic continental shelf and slope of the United StatesGravels of the northeastern part: U.S. Geol. Survey Prof. Paper 529-H, 39 p.

Stanley, D. J., Swift, D. J. P., and Richards, H. G., 1967, Fossiliferous concretions on Georges Bank: Jour. Sed. Petrology, v. 37, p. 1070-1083.

Taney, N. E., 1971, Comments on "Incentives for Ocean Mining": Marine Technology Soc. Jour., v. 5, p. 41-43.

Trumbull, J. V. A., and Hathaway, J. C., 1968, Darkmineral accumulations in beach and dune sands of
Cape Cod and vicinity, in Geological Survey research 1968: U.S. Geol. Survey Prof. Paper 600-B, p. B178-B184.

Uchupi, Elazar, 1966, Structural framework of the Gulf of Maine: Jour. Geophys. Research, v. 71, p. 3013-3028.

1968, Long lost Mytilus: Oceanus, v. 14, no. 3, p. $2-7$.

U.S. Bureau of Mines, 1969, Minerals yearbook, 1968, Volumes 1-2, Metals, minerals, and fuels: Washington, D.C., U.S. Govt. Printing Office, 1208 p.

- 1971, Minerals yearbook, 1969, Volumes 1-2, Metals, minerals and fuels: Washington, D.C., U.S. Govt. Printing Office, 1194 p. 